\title{
Quantifying the selectivity of protein-protein and small molecule interactions with fluorinated tandem bromodomain reader proteins
}

Prakriti Kalra ${ }^{1}$, Logan McGraw ${ }^{1}$, Jennifer R. Kimbrough ${ }^{1}$, Anil K. Pandey ${ }^{1}$, Jonathan Solberg ${ }^{2}$, Huarui Cui ${ }^{1}$, Anand Divakaran, ${ }^{3}$ Kristen John ${ }^{2}$, Jon E. Hawkinson ${ }^{2,3}$, William C.K. Pomerantz ${ }^{* 1,3}$ AUTHOR ADDRESS

${ }^{1}$ Department of Chemistry, University of Minnesota, 207 Pleasant St. SE, Minneapolis, Minnesota, 55455, United States

2 Institute for Therapeutics Discovery and Development, Department of Medicinal Chemistry, University of Minnesota, 717 Delaware Street SE, Minneapolis, Minnesota 55414, United States

${ }^{3}$ Department of Medicinal Chemistry, University of Minnesota $22316^{\text {th }}$ St. SE, Minneapolis, MN 55455, United States

\begin{tabular}{|l|l|}
\hline Table of Contents & Page \\
\hline Methods: Protein Purification & S-2 \\
\hline Table S1: LC/MS Characterization of Proteins & S-3 \\
\hline Table S2: MALDI-TOF MS Characterization of Peptides & S-4 \\
\hline Table S3: $T_{1}$ and T ${ }_{2}$ relaxation values & S-5 \\
\hline $\begin{array}{l}\text { Table S4: Assessment of domain-selectivity of 1,4-acylthiazepanes tested in the pilot } \\
\text { screen }\end{array}$ & S-4 \\
\hline $\begin{array}{l}\text { Figure S1: CD thermal melt curves of unlabeled and fluorinated tandem bromodomains } \\
\text { Figure S2: Fluorescence polarization (FP) direct binding isotherms of unlabeled and } \\
\text { fluorinated (5FW-) BRDT-T }\end{array}$ & S-5 \\
\hline $\begin{array}{l}\text { Figure S3: PrOF NMR experiments with H3 K9ac,K14ac binding to 5FW BRD4-BD1 } \\
\text { and 5FW BRD4-BD2 }\end{array}$ & S-6 \\
\hline
\end{tabular}




\begin{tabular}{|l|l|}
\hline $\begin{array}{l}\text { Figure S4: PrOF NMR experiments with H3 K9ac,K14ac binding to N140A 5FW } \\
\text { BRD4-T }\end{array}$ & S-7 \\
\hline $\begin{array}{l}\text { Figure S5: PrOF NMR experiments with H3 K9ac,K14ac binding to N433A 5FW } \\
\text { BRD4-T }\end{array}$ & S-8 \\
\hline Figure S6: PrOF NMR experiments with H4 K5ac binding to 5FW BRDT-BD1 & S-9 \\
\hline $\begin{array}{l}\text { Figure S7: PrOF NMR experiments with H4 K5ac,K8ac binding to 5FW BRD4-T and } \\
\text { 5FW BRDT-T }\end{array}$ & S-9 \\
\hline $\begin{array}{l}\text { Figure S8: PrOF NMR experiments with RVX-208 binding to 5FW BRD4-BD1 and } \\
\text { 5FW BRD4-BD2 }\end{array}$ & S-10 \\
\hline $\begin{array}{l}\text { Figure S9: PrOF NMR experiment with 1 binding to 5FW BRD4-BD1 and 5FW BRD4- } \\
\text { BD2 }\end{array}$ & S-10 \\
\hline Figure S10: PrOF NMR experiments with (+)-JQ1 binding to 5FW BRD4-BD2 & S-11 \\
\hline Figure S11: PrOF NMR experiments with TH-1 binding to 5FW BRD4-T & S-12 \\
\hline Figure S12: PrOF NMR experiments with TH-11 binding to 5FW BRD4-T & S-13 \\
\hline Figure S13: PrOF NMR experiments with TH-4 binding to 5FW BRD4-T & S-14 \\
\hline Figure S14: PrOF NMR experiments with TH-11 binding to 5FW BRDT-T & S-15 \\
\hline Figure S15: PrOF NMR experiments with TH-4 binding to 5FW BRDT-T & S-16 \\
\hline Figure S16: PrOF NMR experiments with TH-9 binding to 5FW BRDT-T & S-18 \\
\hline Figure S19: Fluorescence polarization competition assay for TH-9 and TH-11 & \\
\hline
\end{tabular}




\begin{tabular}{|l|l|}
\hline HPLC Purity Traces of Peptides & S-43 \\
\hline References & S-44 \\
\hline
\end{tabular}

Methods: Protein Purification. To the cell pellet was added $40 \mathrm{~mL}$ of lysis buffer $(50 \mathrm{mM}$ phosphate, $300 \mathrm{mM} \mathrm{NaCl}, \mathrm{pH} \mathrm{7.4)}$ and $40 \mathrm{mg}$ phenylmethanesulfonyl fluoride (PMSF) and the mixture was allowed to thaw at room temperature for 30 minutes. Cells were put on ice and sonicated in 30 second intervals followed by 60 seconds of cooling for a total of 12 minutes sonication time. The lysed cells were centrifuged at $100000 \mathrm{~g}$ for 30 minutes. The supernatant was decanted from the pelleted cell debris and filtered using Whatman filter paper. Ni affinity purification was done using a Ni HisTrap FF $5 \mathrm{~mL}$ column (GE Healthcare) on an AKTA Fast Protein Liquid Chromatography (FPLC) system by monitoring the absorbance at $280 \mathrm{~nm}$. Proteins were eluted with a $0-100 \%$ gradient of wash buffer $(50 \mathrm{mM}$ phosphate, $100 \mathrm{mM} \mathrm{NaCl}, 40 \mathrm{mM}$ imidazole, $\mathrm{pH}$ 7.4) and elution buffer (50 mM phosphate, $100 \mathrm{mM} \mathrm{NaCl}, 400 \mathrm{mM}$ imidazole, $\mathrm{pH}$ 7.4) across 20 column volumes. Purified protein was then buffer exchanged into storage buffer (50 mM HEPES, 100 mM NaCl, pH 7.4 or 50 mM HEPES, 100 mM NaCl, pH 7.4) using a HiPrep desalting column (GE Healthcare) equilibrated with 1 column volume of buffer. The hexahistidine tag was removed by adding his-tagged Tobacco Etch Virus (TEV) protease and incubating for 4$16 \mathrm{~h}$ at $4^{\circ} \mathrm{C}$. Nickel NTA affinity resin was added, incubated for $2-24 \mathrm{~h}$ at $4^{\circ} \mathrm{C}$, then filtered to remove the TEV. Protein purity was assessed using SDS-polyacrylamide gel electrophoresis (12\% Bis-Tris, $1.0 \mathrm{mM}$ gels. Running conditions: $120 \mathrm{~V}, 90$ minutes in MES buffer). Protein was concentrated to $\sim 25-35 \mu \mathrm{M}$ using Amicon Ultra-15 (Millipore) centrifugal filters with either a 3 $\mathrm{kDa}$ or a $10 \mathrm{kDa}$ molecular weight cut off $(\mathrm{MWCO}=3000 \mathrm{Da}$ or $10000 \mathrm{Da})$, flash frozen and stored at $-20^{\circ} \mathrm{C}$. Quadrupole Time-of-Flight (Q-TOF) LC/MS was used to confirm the identity of the protein and determine percent fluorine incorporation using the following equation. 
$\%$ Incorporation $=\frac{(0 F \text { protein } * 0)+(1 F \text { protein } * 1)+\cdots(n F \text { protein } * n)}{(0 F \text { protein } * n)+(1 F \operatorname{protein} * n)+\cdots(n F \operatorname{protein} * n)} * 100$

Protein masses and fluorine incorporation are shown in table S1.

Table S1: Masses and percent fluorine incorporation determined by LC/MS for bromodomains expressed in this study.

\begin{tabular}{|c|c|c|c|}
\hline Protein & $\begin{array}{l}\text { Calculated } \\
\mathbf{m} / \mathbf{z}(\text { Da) }\end{array}$ & $\begin{array}{ll}\text { Observed } & \mathbf{m} / \mathbf{z} \\
\text { (Da) } & \end{array}$ & $\begin{array}{l}\% \\
\text { Incorporation }\end{array}$ \\
\hline Unlabeled BRD4-T & 47864 & 47866 & N.A. \\
\hline 5FW BRD4-T & 47938 & 47936 & 94 \\
\hline Unlabeled BRDT-T & 47418 & 47418 & N.A. \\
\hline $\mathrm{His}_{6}-5 \mathrm{FW}$ BRDT-T & 49466 & 49458 & 99 \\
\hline $\begin{array}{l}\text { His }_{6}-\mathrm{N} 140 \mathrm{~A} \\
\text { BRD4-T }\end{array}$ & 49967 & 49966 & 95 \\
\hline $\begin{array}{ll}\text { His }_{6}-\mathrm{N} 433 \mathrm{~A} & 5 \mathrm{FW} \\
\text { BRD4-T } & \end{array}$ & 49967 & 49966 & 95 \\
\hline 5FW BRD4-BD1 & 15137 & 15135 & 98 \\
\hline 5FW BRD4-BD2 & 15054 & 15054 & 95 \\
\hline 5FW BRDT-BD1 & 14184 & 14184 & 95 \\
\hline
\end{tabular}

Table S2: Peptide theoretical and observed masses using MALDI-TOF MS.

\begin{tabular}{|c|c|c|c|}
\hline Peptide & Sequence & $\begin{array}{l}\text { Calculated } \\
{[\mathbf{M}+\mathbf{H}]^{+}}\end{array}$ & $\begin{array}{l}\text { Observed } \\
{[\mathbf{M}+\mathbf{H}]^{+}}\end{array}$ \\
\hline H3 K9ac,K14ac & $\begin{array}{l}\mathrm{H}_{2} \mathrm{~N}-\mathrm{YARTKQTARKacSTGGKacAPRKQL-} \\
\mathrm{C}(\mathrm{O}) \mathrm{NH}_{2}\end{array}$ & 2429.36 & 2429.49 \\
\hline H4 K5ac & $\begin{array}{l}\mathrm{H}_{2} \mathrm{~N}-\mathrm{YSGRGKacGGKGLGKGGAKRHRK-} \\
\mathrm{C}(\mathrm{O}) \mathrm{NH}_{2}\end{array}$ & 2196.56 & 2196.08 \\
\hline H4 K5ac,K8ac & $\begin{array}{l}\mathrm{H}_{2} \mathrm{~N}-Y S G R G K a c G G K a c G L G K G G A K R H R K- \\
\mathrm{C}(\mathrm{O}) \mathrm{NH}_{2}\end{array}$ & 2238.27 & 2238.19 \\
\hline
\end{tabular}

Table S3: $T_{1}$ and $T_{2}$ relaxation values for fluorinated tandem proteins and individual domains. 


\begin{tabular}{|l|l|l|l|}
\hline Protein & ${ }^{19} \mathbf{F}$ NMR resonance & $\mathbf{T}_{\mathbf{1}}(\mathbf{m s})$ & $\mathbf{T}_{\mathbf{2}}(\mathbf{m s})$ \\
\hline 5FW BRD4-BD1 & W75 & 610 & 11 \\
\hline & W120 & 624 & 13 \\
\hline 5FW BRD4-BD2 & W81 & 751 & 16 \\
\hline 5FW BRD4-T & W75 and W120 & 691 & 11 \\
\hline & W81 & 976 & 10 \\
\hline & W374 & 838 & 13 \\
\hline 5FW BRDT-BD1 & W44 & 718 & 10 \\
\hline & W50 & 696 & 7 \\
\hline 5FW BRDT-T & W44 & 882 & 11 \\
\hline & W50 & 1176 & 5 \\
\hline & W293 & 910 & 5 \\
\hline
\end{tabular}

Table S4: Assessment of domain-selectivity of 1,4-acylthiazepanes tested in the pilot screen ${ }^{a}$

\begin{tabular}{|l|l|l|}
\hline Ligand (50 $\mu \mathrm{M})$ & Percent drop in & Percent drop in W374 \\
& W81 ${ }^{19}$ F resonance & ${ }^{19}$ F resonance area \\
& area & \\
\hline AP-4-35 & + & + \\
\hline AP-4-18 & + & + \\
\hline DP-1-146 & + & ++++ \\
\hline DP-1-142 & + & + \\
\hline DP-1-144 & + & + \\
\hline
\end{tabular}




\begin{tabular}{|l|l|l|}
\hline DP-1-140 & + & + \\
\hline E2(R) & ++ & ++++ \\
\hline E1(S) & +++ & ++++ \\
\hline DP-2-48 & +++ & ++++ \\
\hline JRK-01-73 & +++ & ++++ \\
\hline JRK-01-68 & ++++ & ++++ \\
\hline JRK-01-65 & +++ & ++++ \\
\hline
\end{tabular}

$\mathrm{a}:+=0-25 \% ;++=25-50 \% ;+++=50-75 \% ;++++=75-100 \%$
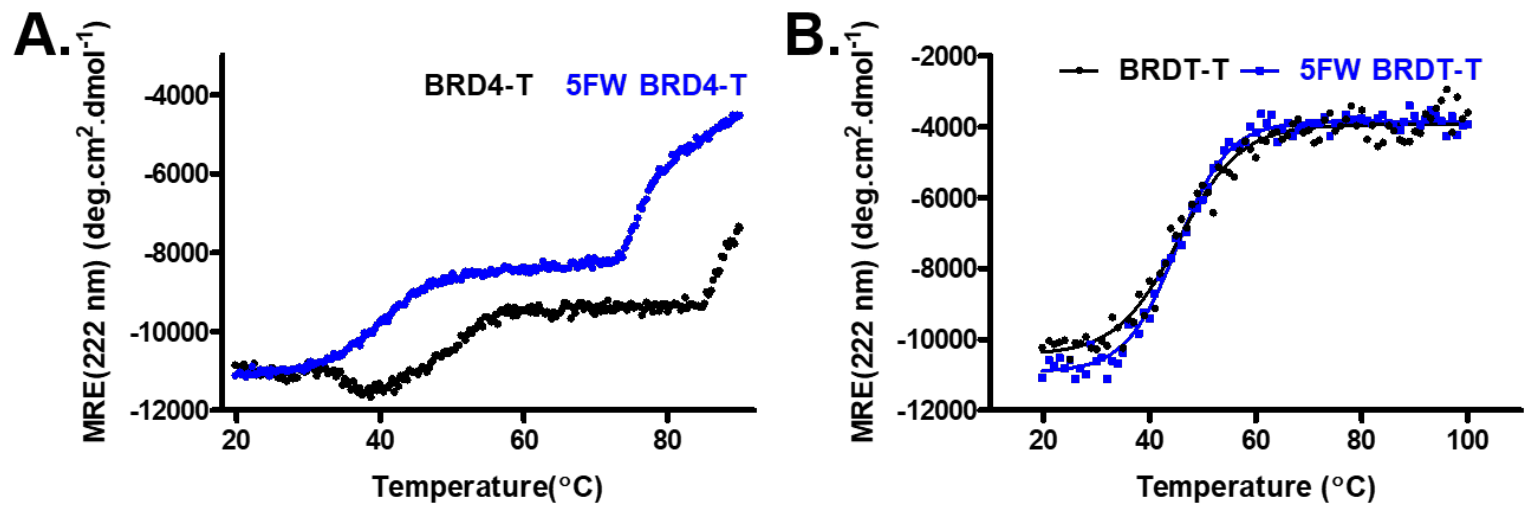

Figure S1: CD thermal melt curves of unlabeled and fluorinated (5FW-) (A) BRD4-T and (B) BRDT-T.

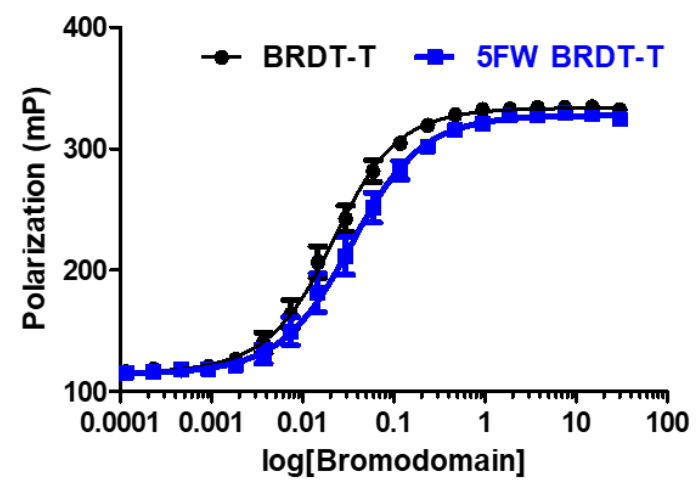

Figure S2: Fluorescence polarization (FP) direct binding isotherms of unlabeled and fluorinated (5FW-) BRDT-T. 


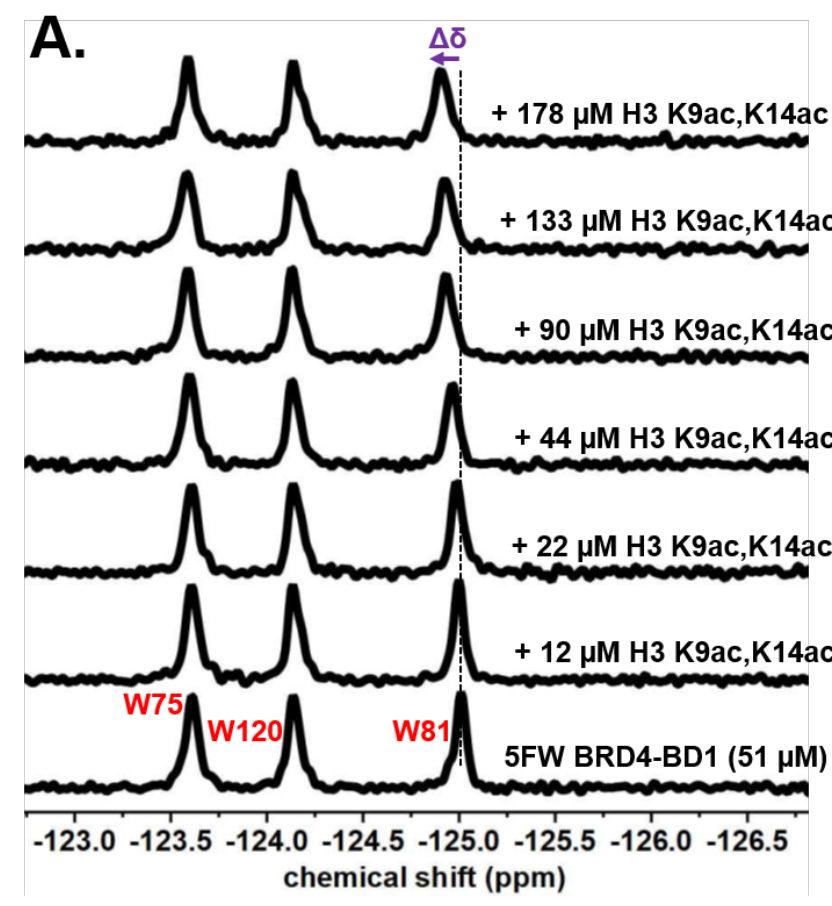

B.
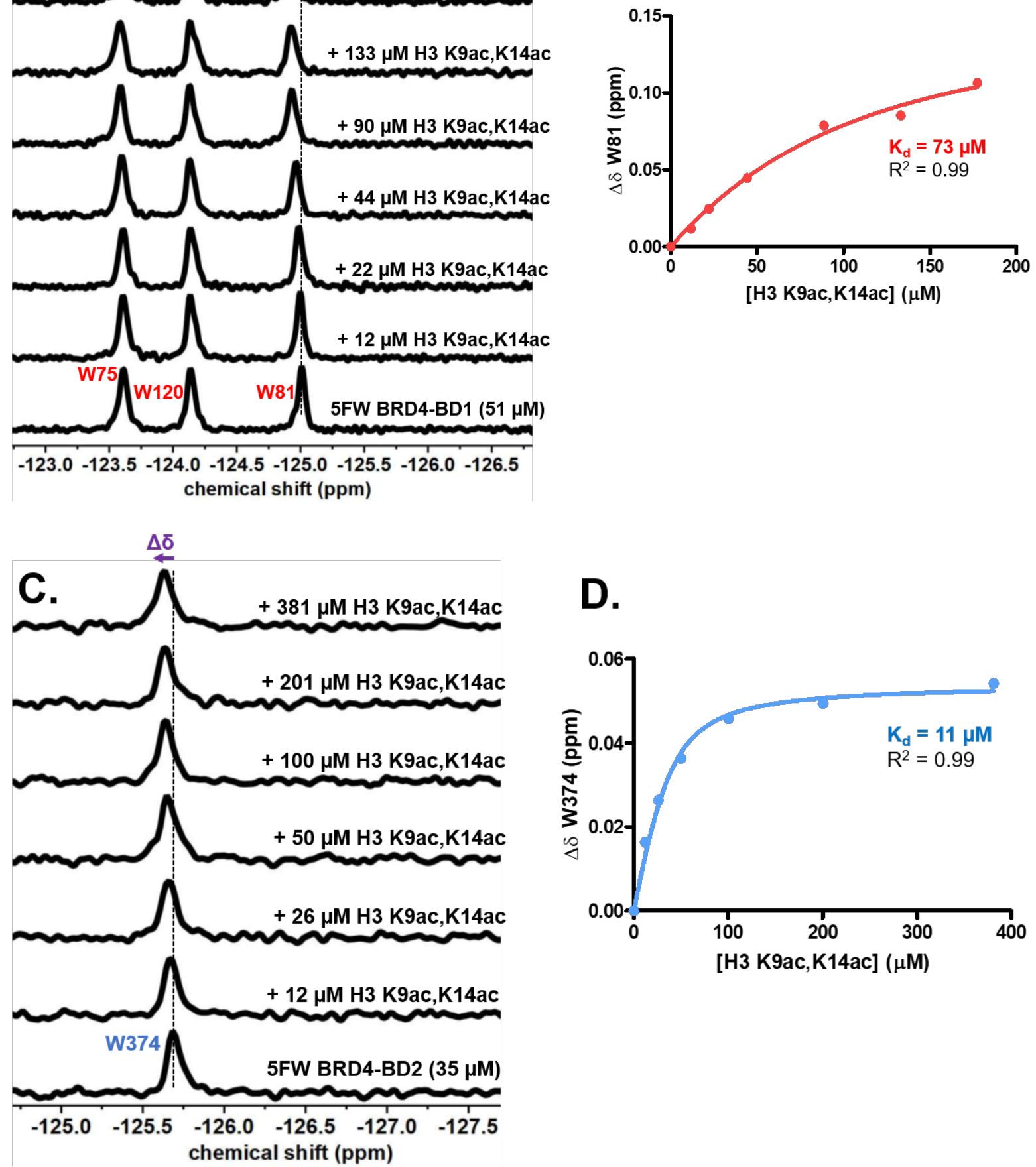

Figure S3: PrOF NMR experiments with H3 K9ac,K14ac binding to 5FW BRD4-BD1 and 5FW BRD4-BD2. (A) Stacked ${ }^{19} \mathrm{~F}$ NMR spectra with an increasing concentration of the H3 K9ac,K14ac peptide with $51 \mu \mathrm{M}$ 5FW BRD4-BD1 and (B) Binding isotherm of H3 K9ac,K14ac binding to 
5FW-BRD4-BD1. (C) Stacked ${ }^{19}$ F NMR spectra with an increasing concentration of the H3 K9ac,K14ac peptide with $35 \mu \mathrm{M}$ 5FW BRD4-BD2 and (D) Binding isotherm of H3 K9ac,K14ac binding to 5FW-BRD4-BD2. W81 and W374, are the WPF shelf tryptophans in BD1 and BD2 of BRD4-T, colored red and blue, respectively.
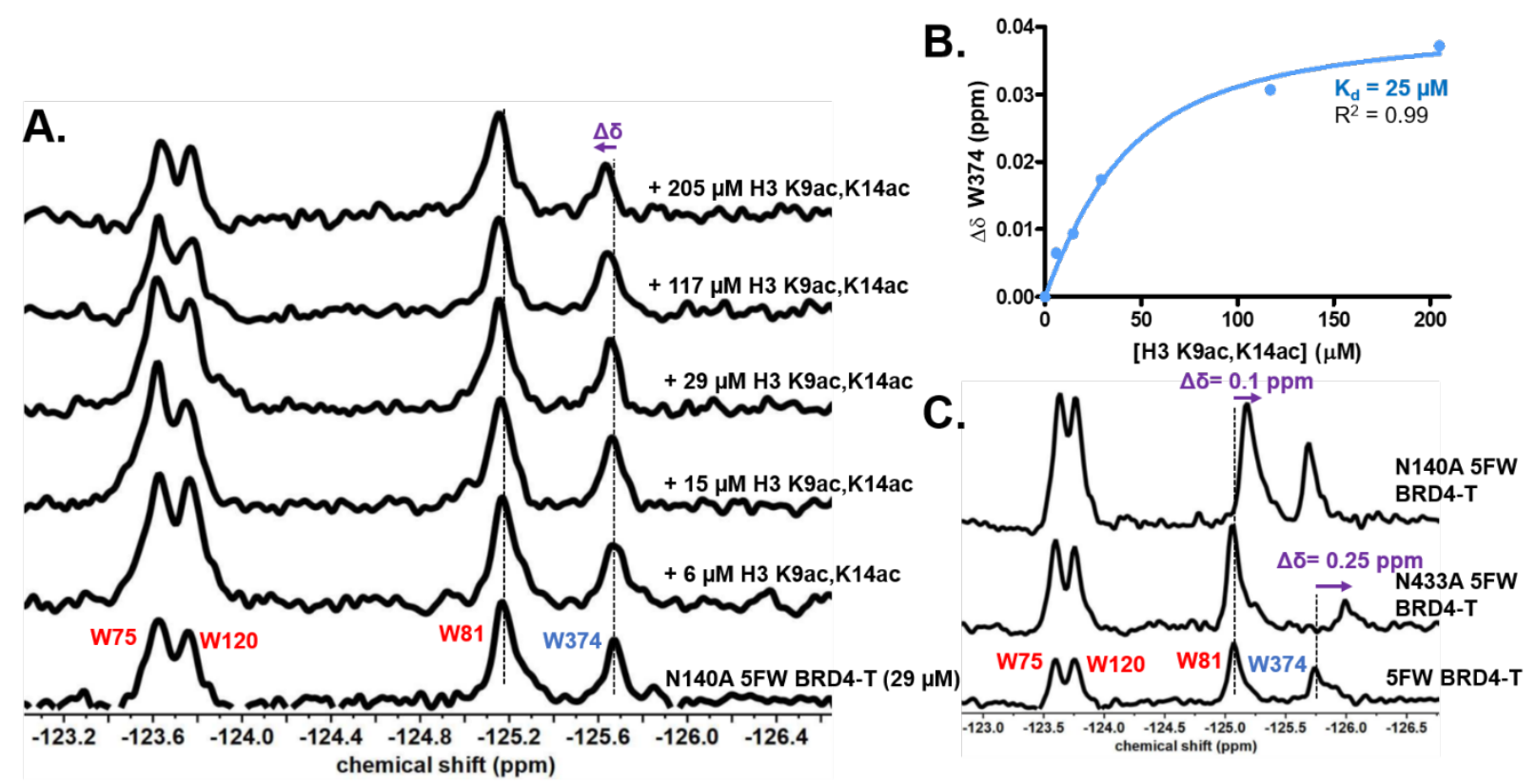

Figure S4: PrOF NMR experiments with H3 K9ac,K14ac binding to N140A 5FW BRD4-T. (A)

Stacked ${ }^{19}$ F NMR spectra and (B) binding isotherm of H3 K9ac,K14ac peptide with $29 \mu$ M N140A 5FW BRD4-T. (C) Stacked ${ }^{19}$ F NMR spectra of N140A, N433A and unmutated 5FW BRD4-T. W81 and W374, are the WPF shelf tryptophans in BD1 and BD2 of BRD4-T, colored red and blue, respectively. Changes in the chemical shift $(\Delta \delta)$ are indicated in purple. W81 moves upfield in N140 5FW BRD4-T and W374 broadens and moves upfield by $0.25 \mathrm{ppm}$ when aligned with ${ }^{19} \mathrm{~F}$ NMR spectra of unmutated 5FW BRD4-T. 


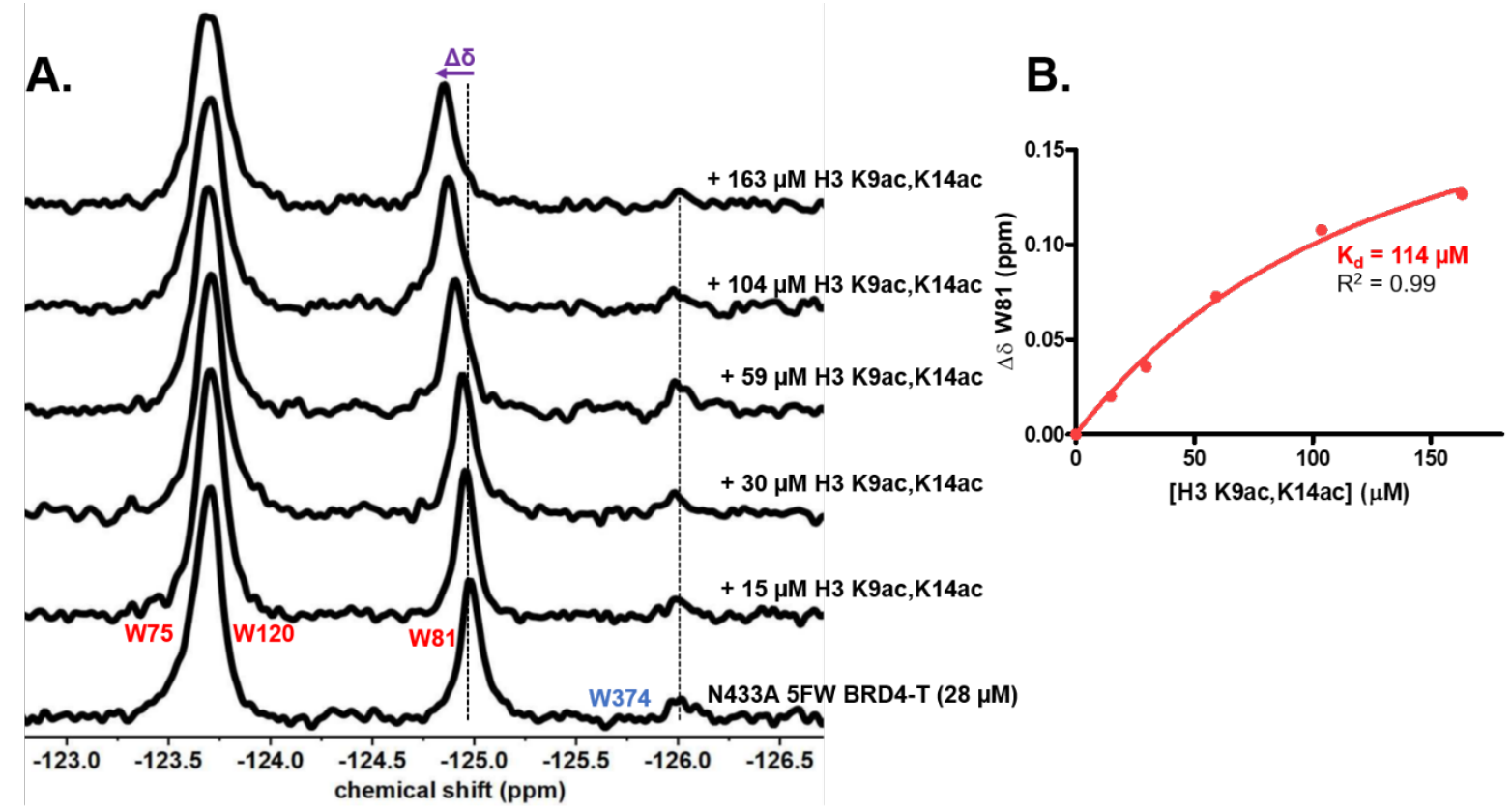

Figure S5: PrOF NMR experiments with H3 K9ac,K14ac binding to N433A 5FW BRD4-T. (A) Stacked ${ }^{19}$ F NMR spectra and (B) binding isotherm of H3 K9ac,K14ac peptide with $28 \mu \mathrm{M}$ N433A 5FW BRD4-T. W81 and W374, are the WPF shelf tryptophans in BD1 and BD2 of BRD4-T, colored red and blue, respectively. Changes in the chemical shift $(\Delta \delta)$ are indicated in purple.
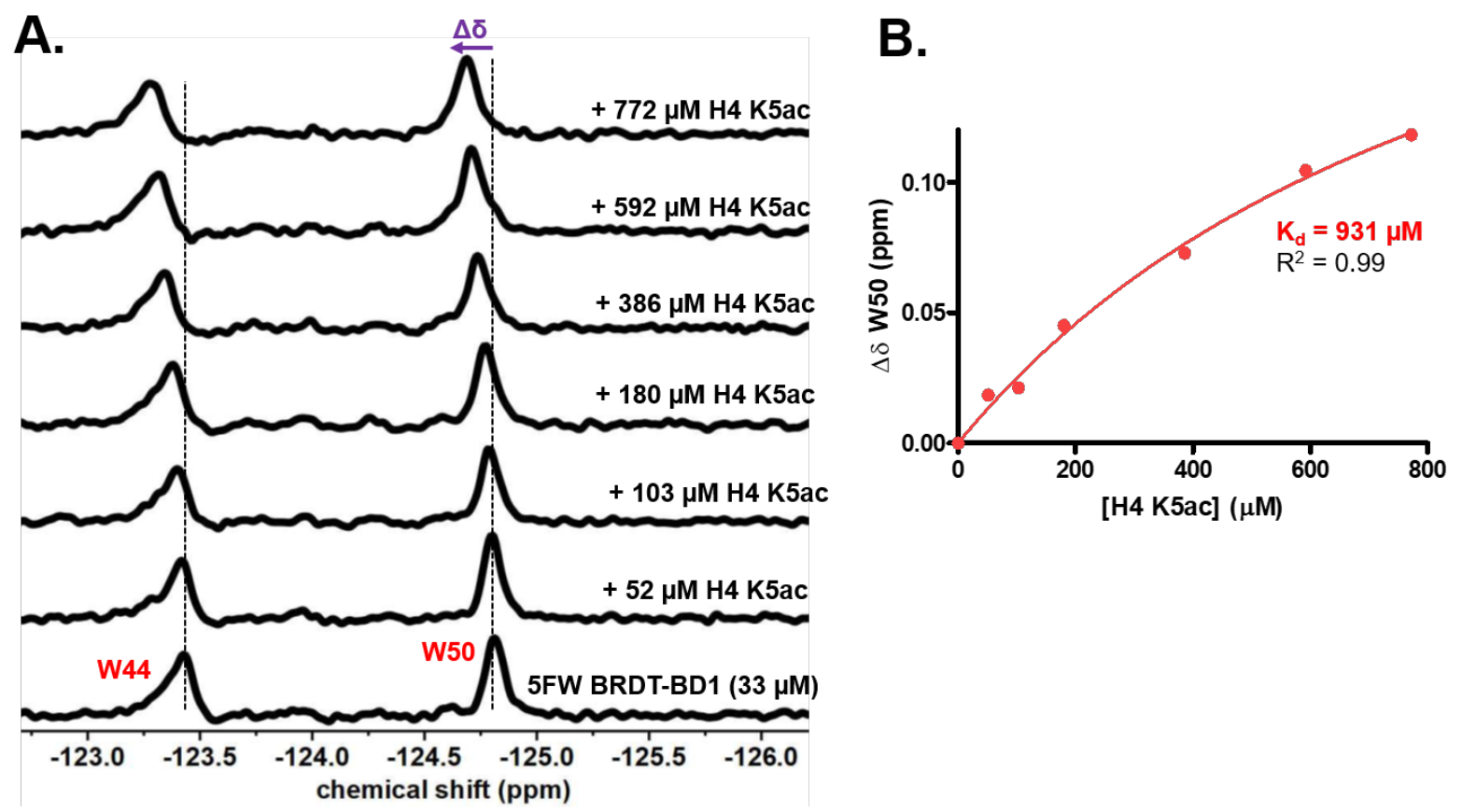
Figure S6: PrOF NMR experiments with H4 K5ac binding to 5FW BRDT-BD1. (A) Stacked ${ }^{19} \mathrm{~F}$ NMR spectra with an increasing concentration of the H4 K5ac with $33 \mu \mathrm{M} 5 \mathrm{FW}$ BRDT-BD1 and (B) Binding isotherm of $\mathrm{H} 4 \mathrm{~K} 5 \mathrm{ac}$ binding to 5FW BRDT-BD1. W50 is the WPF shelf tryptophan in BD1 of BRDT-T, colored red. Change in the chemical shift $(\Delta \delta)$ is shown in purple.
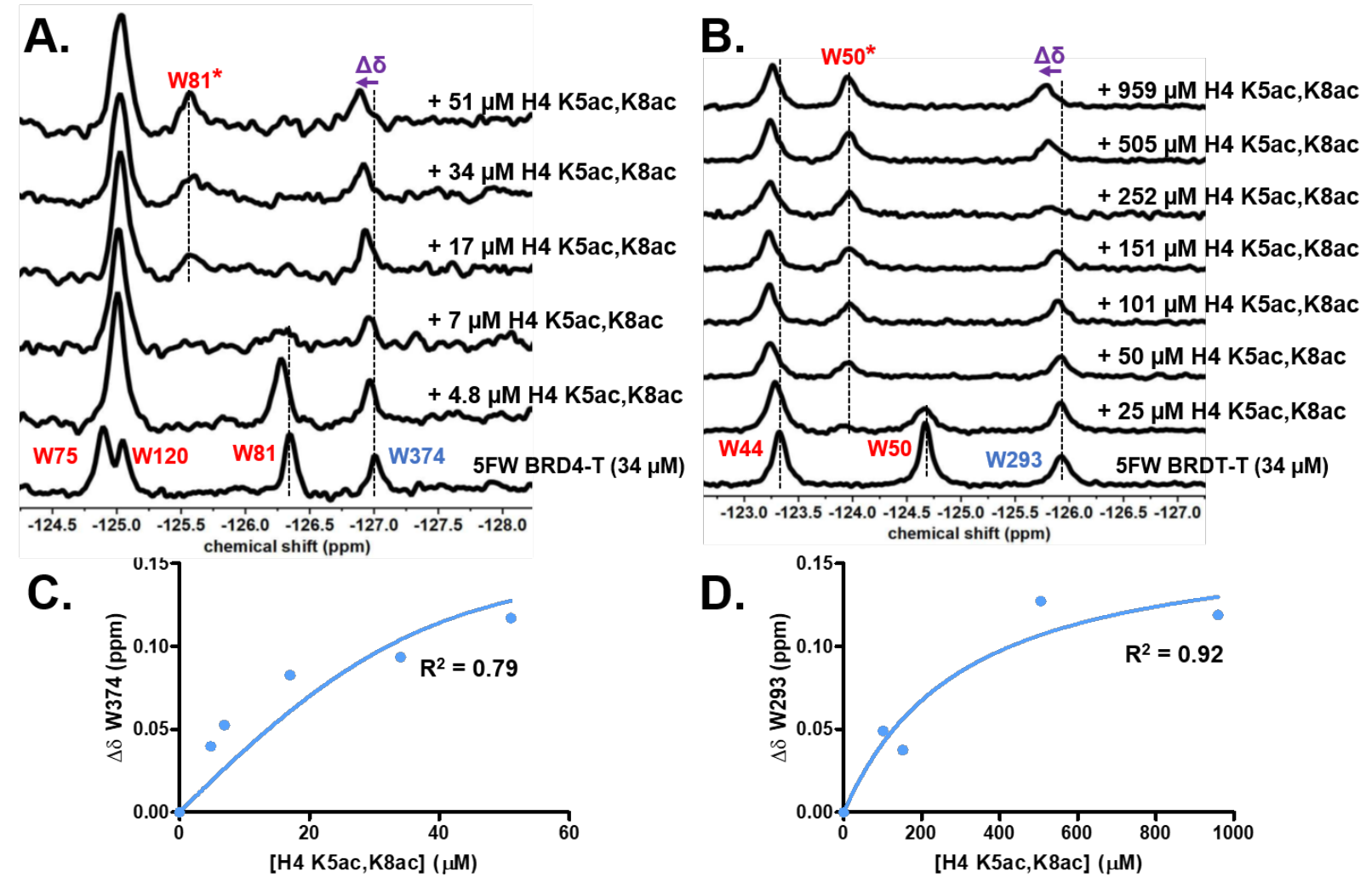

Figure S7: PrOF NMR experiments with H4 K5ac,K8ac binding to 5FW BRD4-T and 5FW BRDT-T. Stacked ${ }^{19}$ F NMR spectra with an increasing concentration of the H4 K5ac,K8ac with (A) $34 \mu \mathrm{M}$ 5FW BRD4-T and (B) $34 \mu \mathrm{M}$ 5FW BRDT-T. Binding isotherm of H4 K5ac,K8ac binding to (C) 5FW BRD4-T and (D) 5FW BRDT-T. W81 and W374, W50 and W293 are the WPF shelf tryptophans in BD1 and BD2 of BRD4-T and BRDT-T, colored red and blue, respectively. Change in the chemical shift $(\Delta \delta)$ is shown in purple. $K_{d}$ was not determined due to the poor fit of the data. 

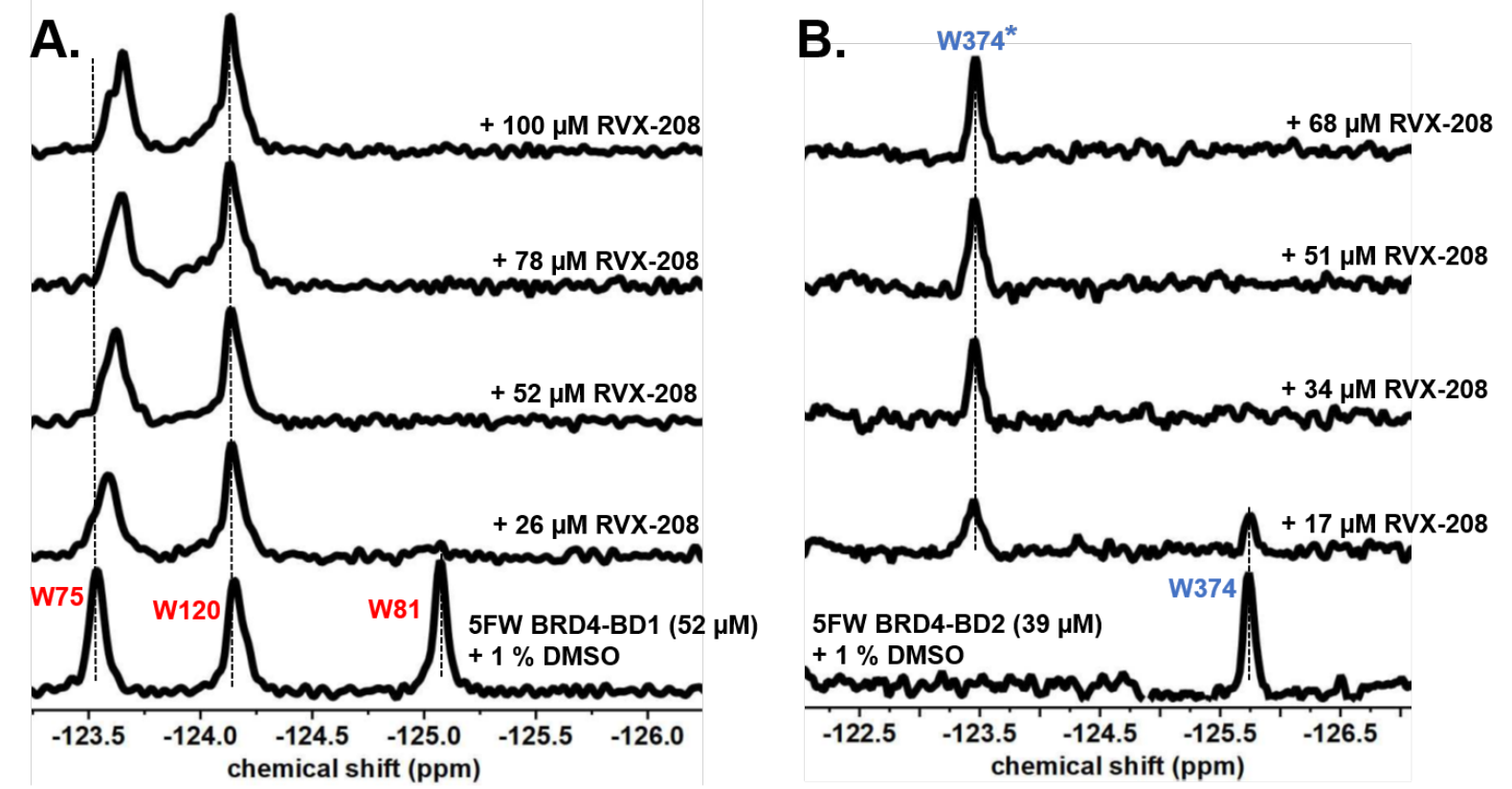

Figure S8: PrOF NMR experiments with RVX-208 binding to (A) 5FW BRD4-BD1 (52 $\mu$ M) and (B) 5FW BRD4-BD2 $(34 \mu \mathrm{M})$. W81 and W374, are the WPF shelf tryptophans in BD1 and BD2 of BRD4-T, colored red and blue, respectively. ${ }^{19} \mathrm{~F}$ resonances for the ligand-bound protein are indicated with an asterisk.
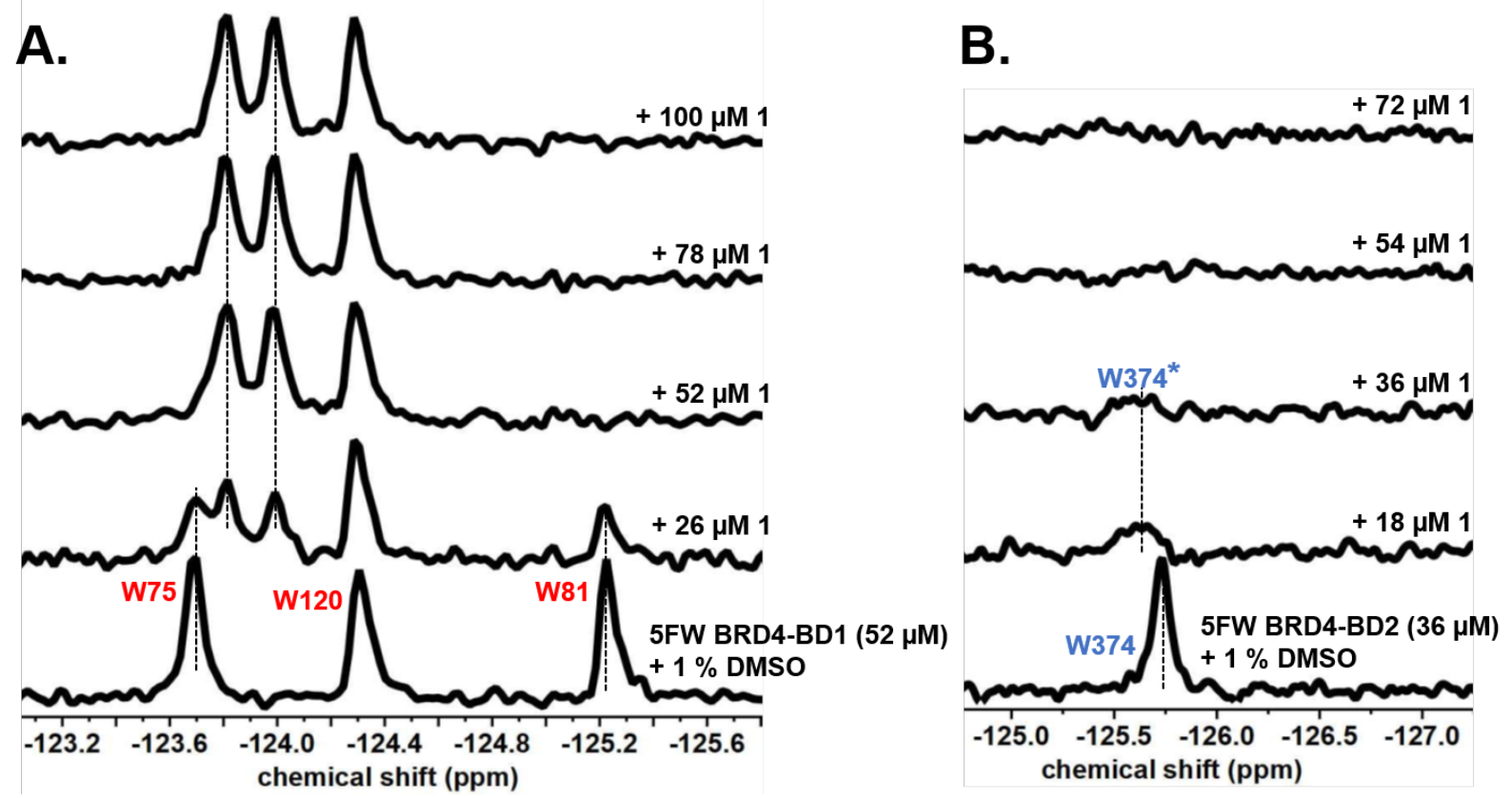

Figure S9: PrOF NMR experiment with 1 binding to (A) 5FW BRD4-BD1 (52 $\mu \mathrm{M})(\mathrm{B})$ 5FW BRD4-BD2 $(36 \mu \mathrm{M})$. W81 and W374, are the WPF shelf tryptophans in BD1 and BD2, colored 
red and blue respectively. ${ }^{19} \mathrm{~F}$ resonances for the ligand-bound protein are indicated with an asterisk.

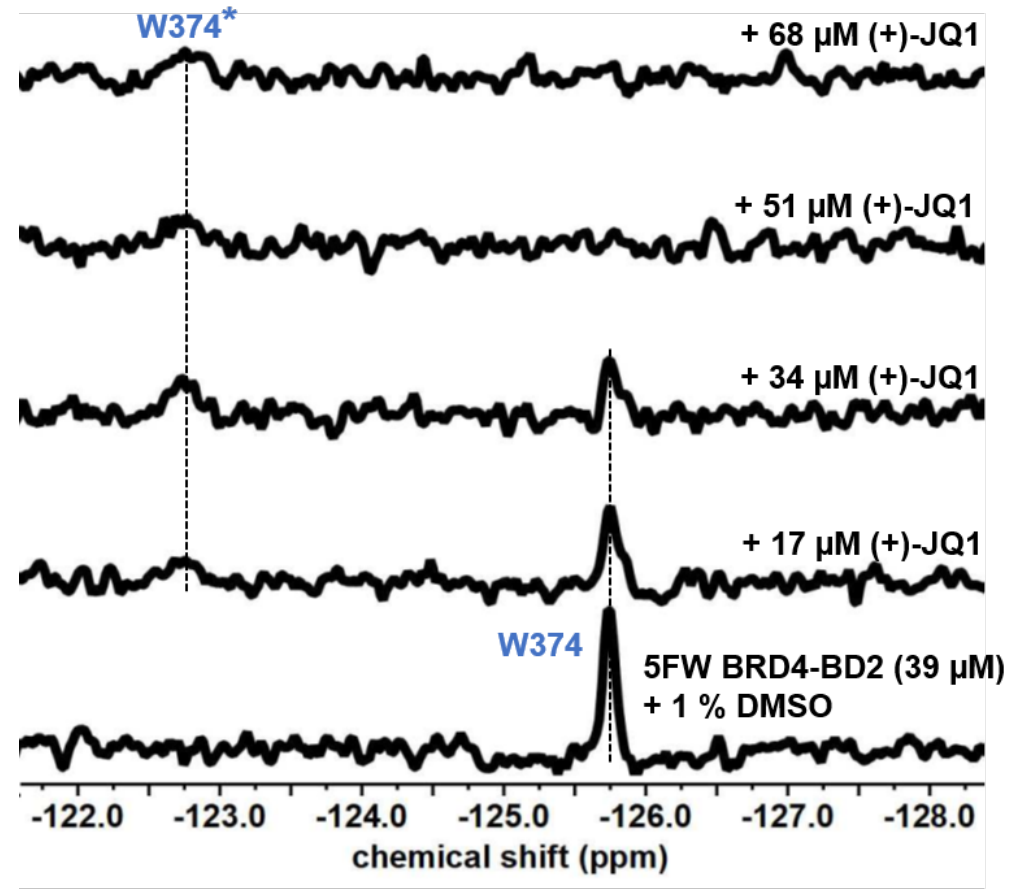

Figure S10: PrOF NMR experiments with (+)-JQ1 binding to 5FW BRD4-BD2 $(39 \mu \mathrm{M})$. W81 and W374, are the WPF shelf tryptophans in BD1 and BD2, colored red and blue respectively. ${ }^{19} \mathrm{~F}$ resonances for the ligand-bound protein are indicated with an asterisk. PrOF NMR experiment with (+)-JQ1 binding to 5FW BRD4-BD1 has been reported before. ${ }^{1}$ 


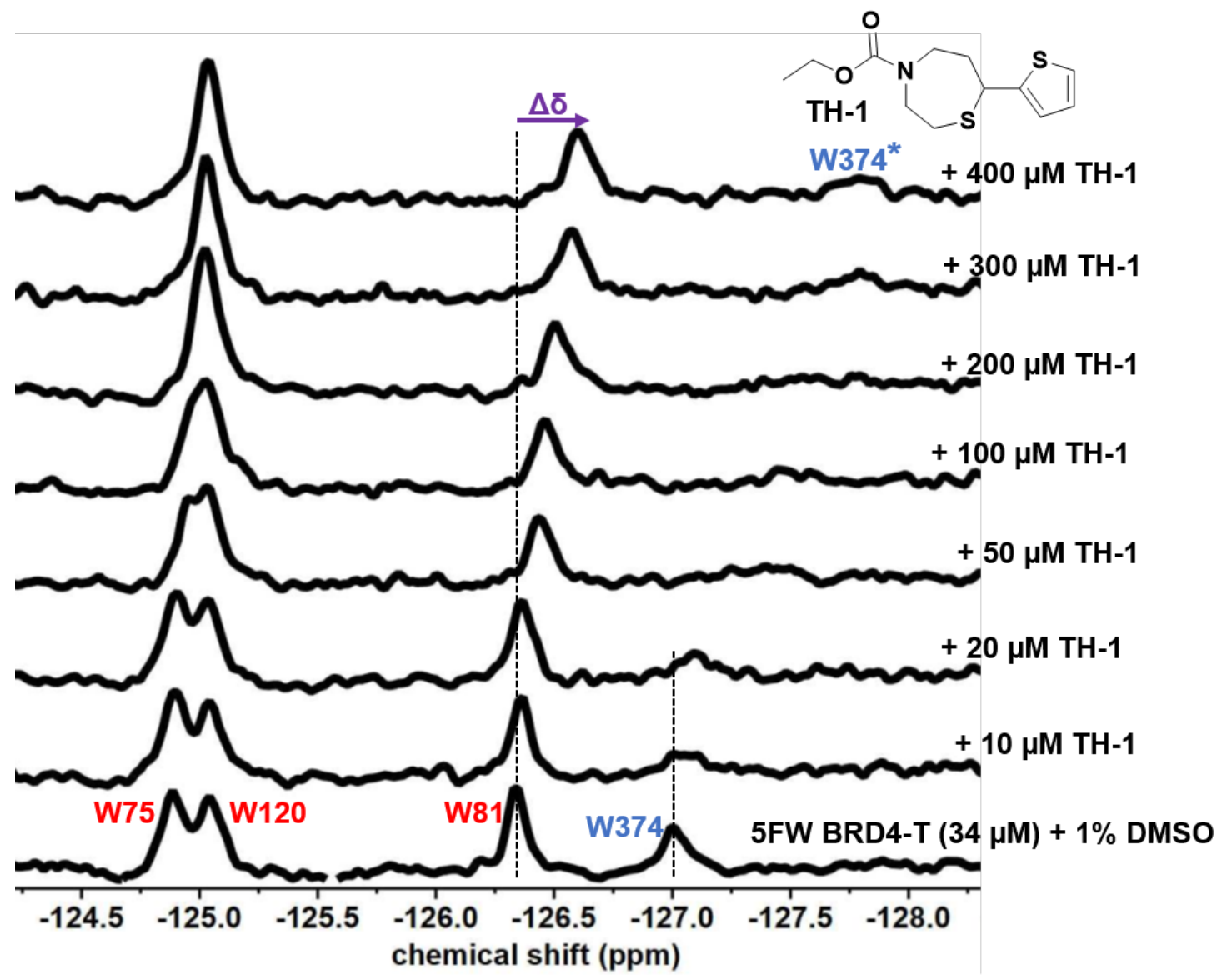

Figure S11: PrOF NMR experiments with TH-1 binding to 5FW BRD4-T. Stacked ${ }^{19}$ F NMR spectra with an increasing concentration of TH-1 with $34 \mu \mathrm{M}$ 5FW BRD4-T. W81 and W374, are the WPF shelf tryptophans in BD1 and BD2 of BRD4-T, colored red and blue respectively. Change in the chemical shift $(\Delta \delta)$ is shown in purple. 


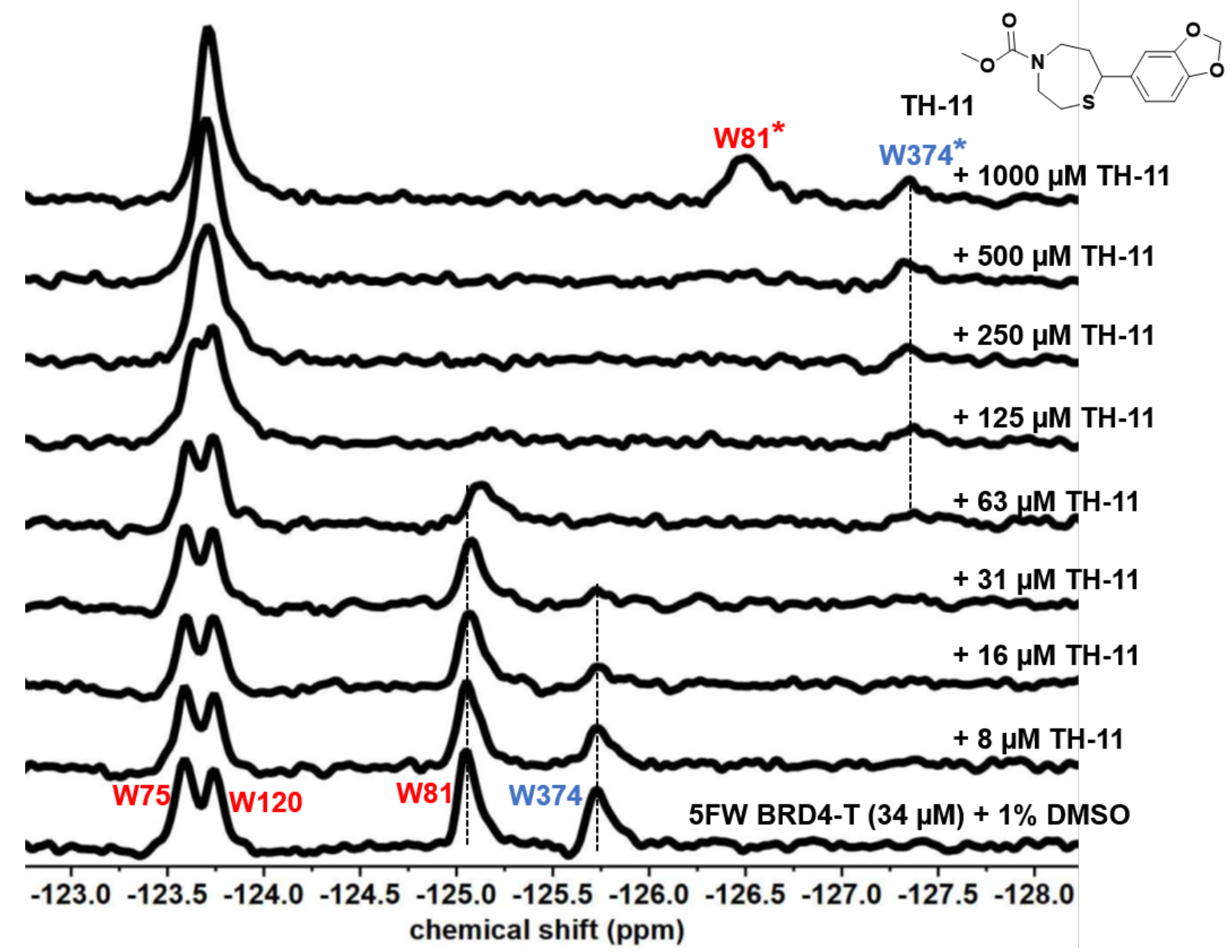

Figure S12: Stacked ${ }^{19}$ F NMR spectra with an increasing concentration of TH-11 with $34 \mu \mathrm{M}$ 5FW BRD4-T. W81 and W374, are the WPF shelf tryptophans in BD1 and BD2 of BRD4-T, colored red and blue respectively 


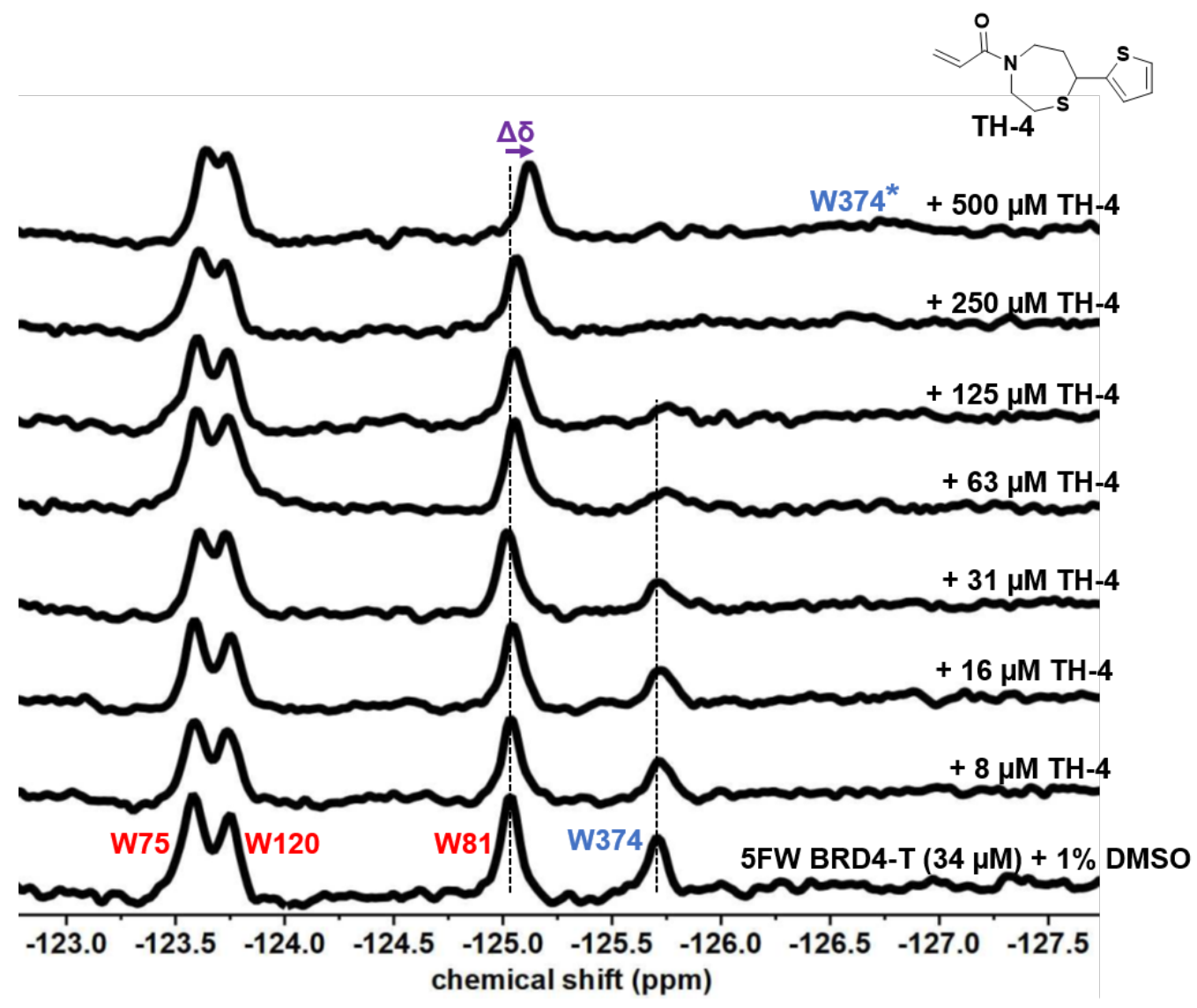

Figure S13: Stacked ${ }^{19}$ F NMR spectra with an increasing concentration of TH-4 with $34 \mu \mathrm{M} 5 \mathrm{FW}$ BRD4-T. W81 and W374, are the WPF shelf tryptophans in BD1 and BD2 of BRD4-T, colored red and blue respectively. Change in the chemical shift $(\Delta \delta)$ is shown in purple. 


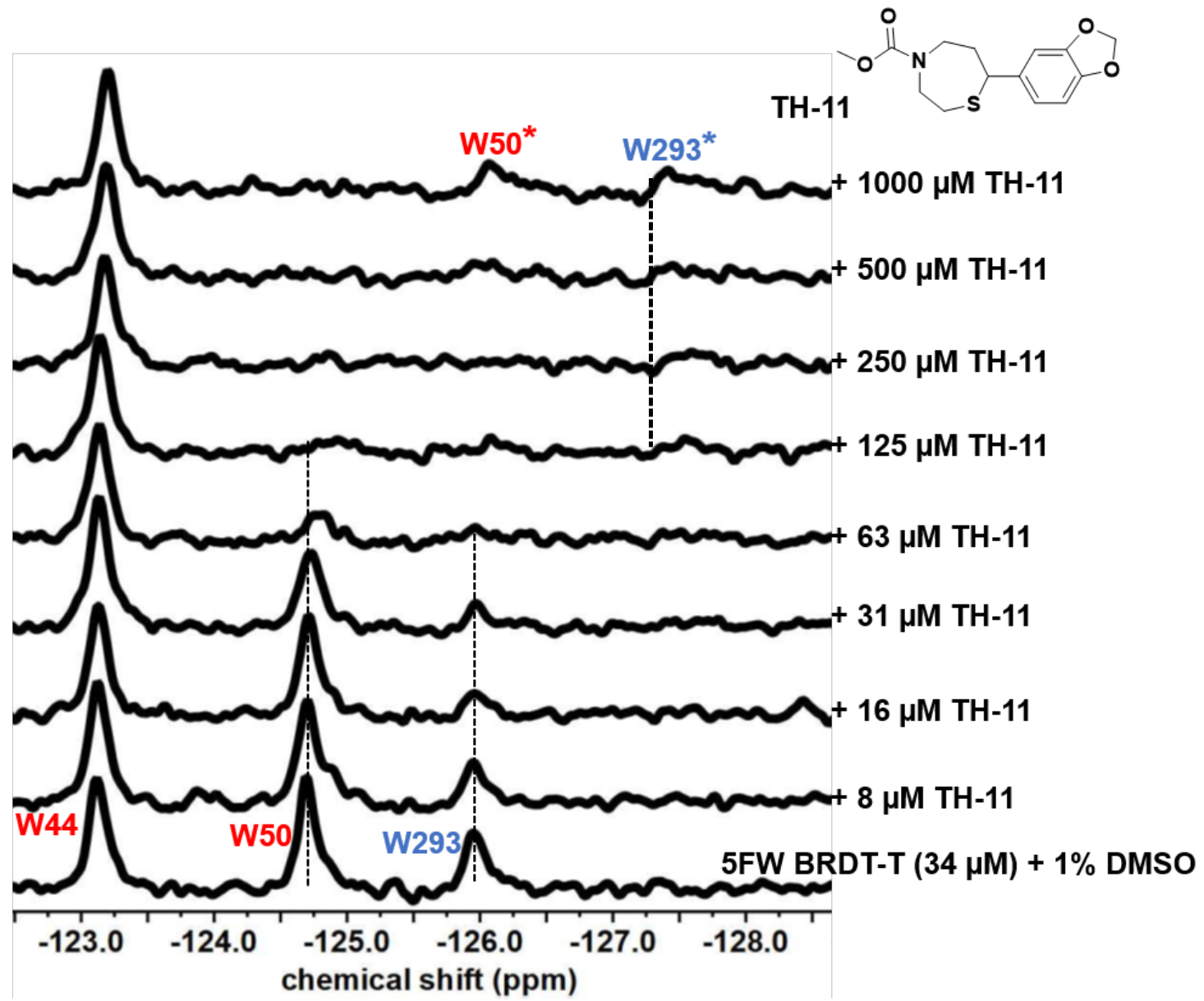

Figure S14: Stacked ${ }^{19}$ F NMR spectra with an increasing concentration of TH-11 with $34 \mu \mathrm{M}$ 5FW BRDT-T. W50 and W293 are the WPF shelf tryptophans in domains BD1 and BD2 respectively of BRDT-T, colored red and blue respectively. 


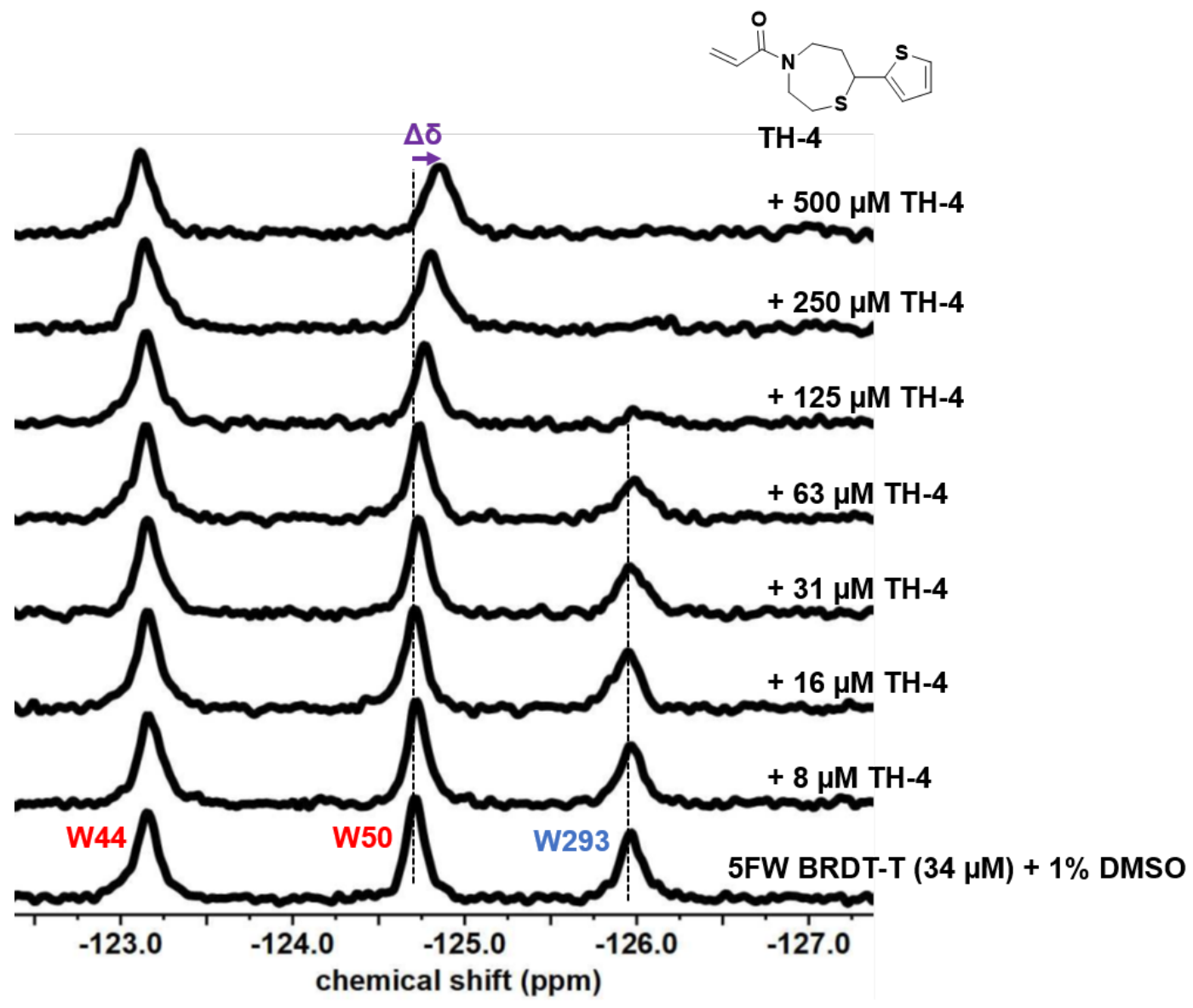

Figure S15: PrOF NMR experiments with TH-4 binding to 5FW BRDT-T. Stacked ${ }^{19} \mathrm{~F}$ NMR spectra with an increasing concentration of TH-3 with $33 \mu \mathrm{M}$ 5FW BRDT-T. W50 and W293 are the WPF shelf tryptophans in BD1 and BD2 respectively of BRDT-T, colored red and blue respectively. Change in the chemical shift $(\Delta \delta)$ is shown in purple. 


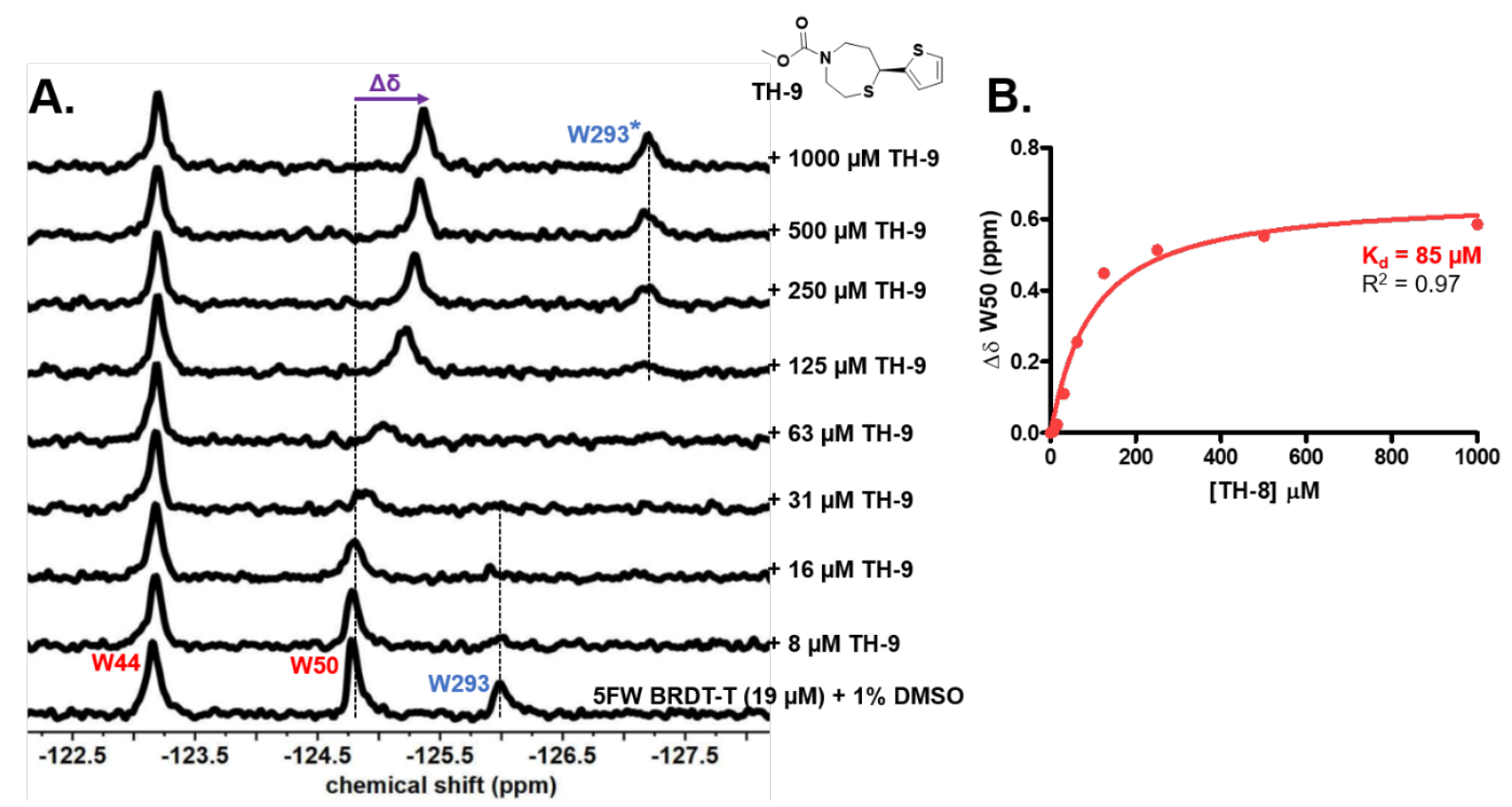

Figure S16: PrOF NMR experiments with TH-9 binding to 5FW BRDT-T. (A) Stacked ${ }^{19}$ F NMR spectra with an increasing concentration of TH-9 with $19 \mu \mathrm{M}$ 5FW BRDT-T. (B) Binding isotherm obtained by plotting $\Delta \delta$ of W50 against ligand concentration. W50 and W293 are the WPF shelf tryptophans in $\mathrm{BD} 1$ and $\mathrm{BD} 2$ of $\mathrm{BRDT}-\mathrm{T}$, colored red and blue respectively. Change in the chemical shift $(\Delta \delta)$ is shown in purple. 


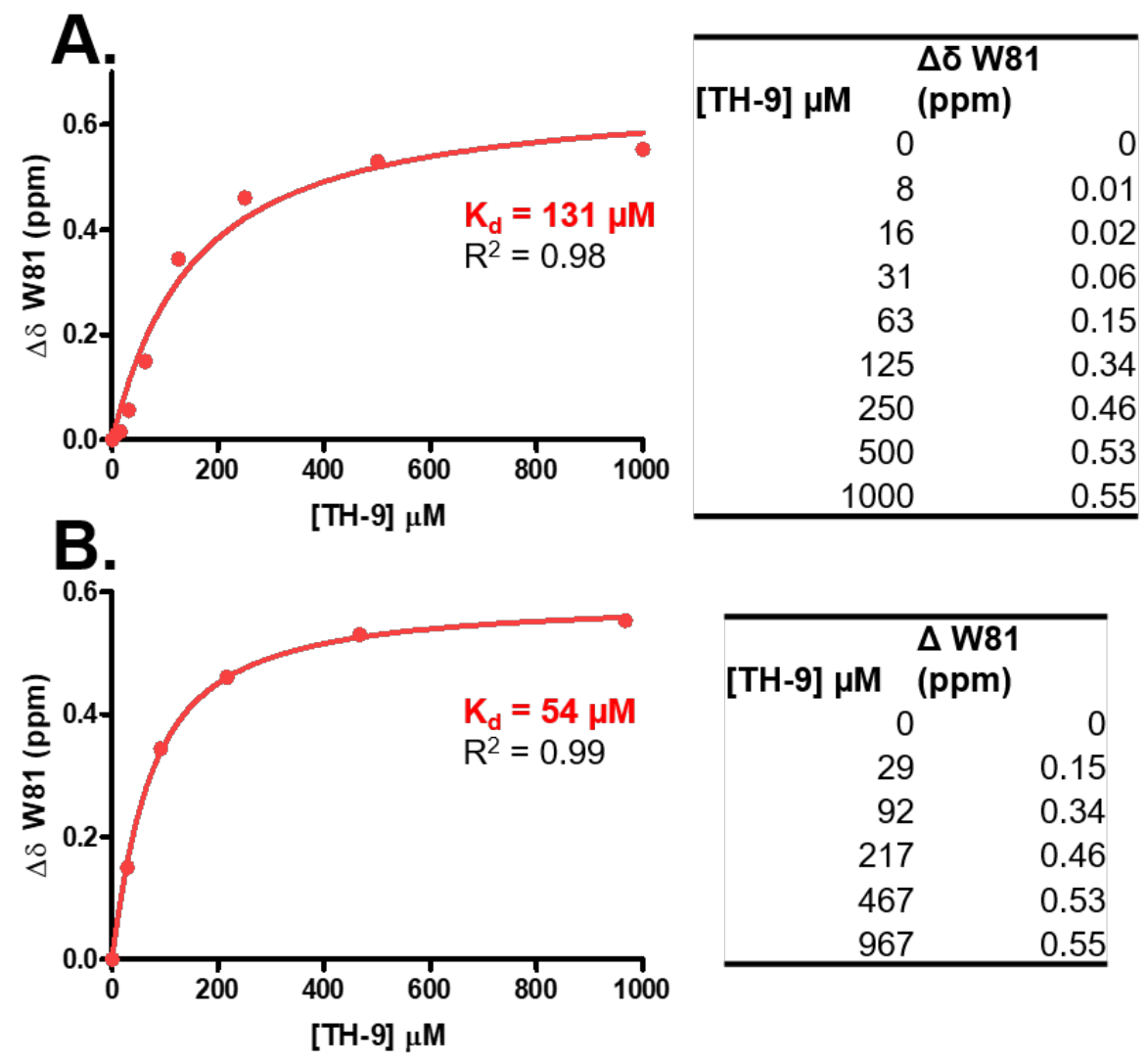

Figure S17: PrOF NMR experiments with TH-9 binding to 5FW BRD4-T. (A) Binding isotherm obtained by plotting $\Delta \delta$ of W81 against (B) total ligand concentration and (C) adjusted ligand concentration accounted for ligand depletion from binding to BD2. 


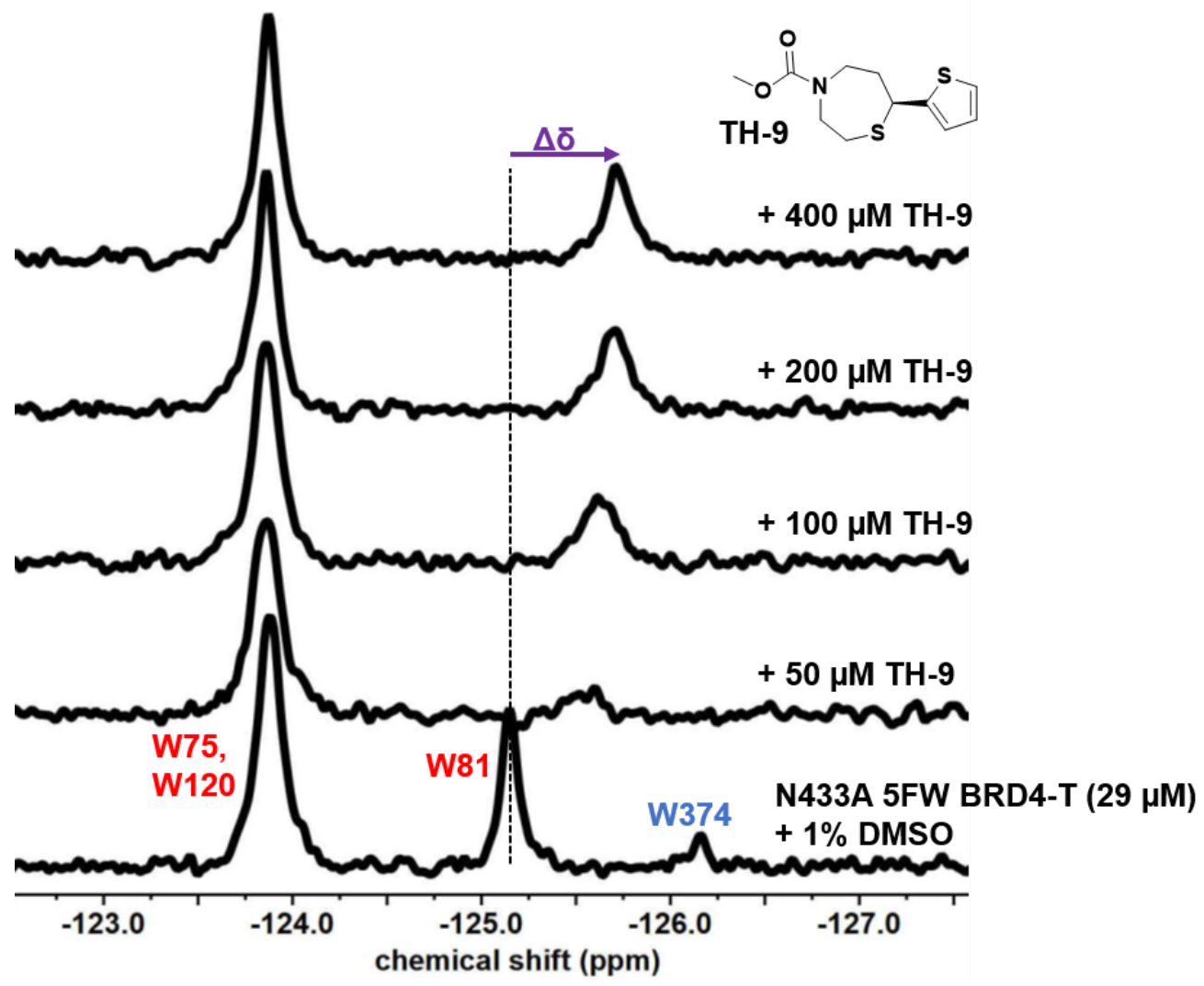

Figure S18: PrOF NMR experiments with TH-9 binding to N433A 5FW BRD4-T. Stacked ${ }^{19} \mathrm{~F}$ NMR spectra with an increasing concentration of TH-9 with $29 \mu \mathrm{M}$ N433A 5FW BRD4-T is shown. W81 and W374 are the WPF shelf tryptophans in BD1 and BD2 of BRD4-T, colored red and blue respectively. 

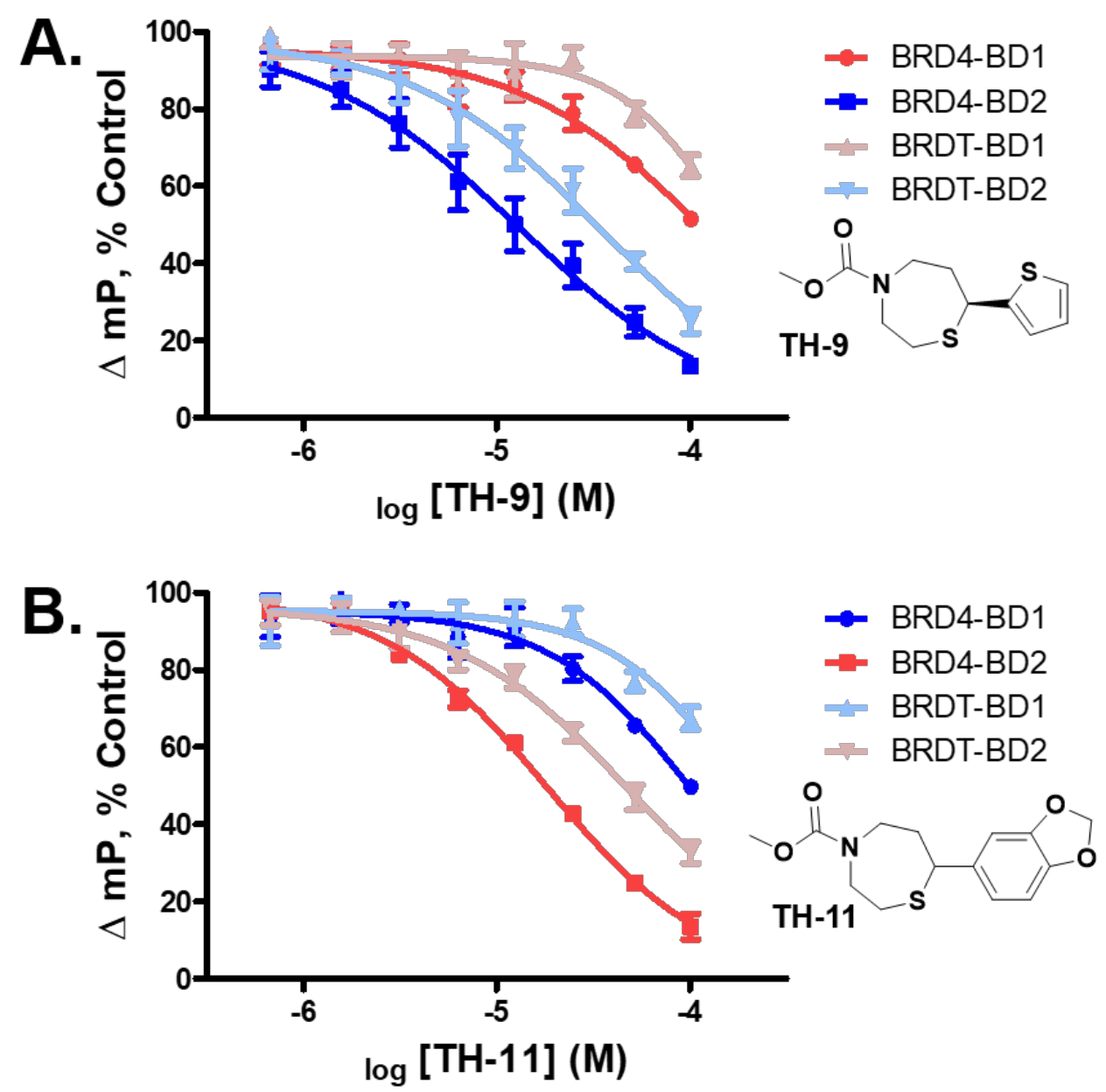

Figure S19: Fluorescence polarization competition assay for $\mathrm{TH}-9$ (A) and $\mathrm{TH}-11$ (B) displacement of the pan-BET inhibitor FP probe, SG3-179-BODIPY (Probe 16) ${ }^{2}$ to BET bromodomains. $\mathrm{n}=3-4$ independent experiments. 


\section{Synthetic procedures}

Compound TH-1 was synthesized as described previously. Spectral data correlated to the previously reported data. ${ }^{3}$

Compounds TH-2,-3,-5,-7,-8, $-9,-10$ and S-1, $-2 \mathrm{a}$, and $-3 \mathrm{a}$ were synthesized as described previously. Spectral data correlated to the previously reported data. ${ }^{4}$

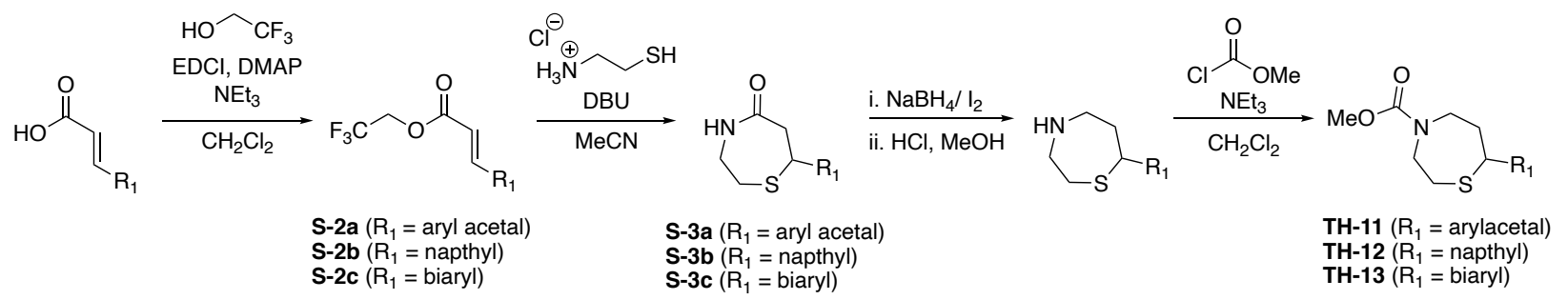

Scheme S-1: General Synthetic Scheme

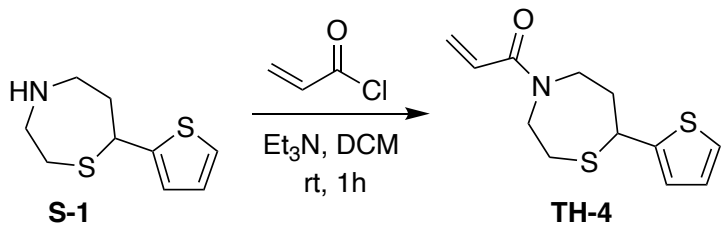

Compound S-1 (70 mg, $0.35 \mathrm{mmol})$ was dissolved in DCM (5 mL), along with acryloyl chloride $(44.0 \mu \mathrm{L}, 0.53 \mathrm{mmol})$, and triethylamine $(98.0 \mu \mathrm{L}, 0.70 \mathrm{mmol})$ and the resulting solution was stirred at room temperature for $1 \mathrm{~h}$. Reaction was quenched with $\mathrm{H}_{2} \mathrm{O}(5 \mathrm{~mL})$ and further extracted with $\mathrm{DCM}(3 \times 5 \mathrm{~mL})$. The combined organic layer was dried over $\mathrm{MgSO}_{4}$. The organic layer was filtered, concentrated, and purified on a Combiflash RF system (hexanes/EtOAc, 0-100\% EtOAc) to afford compound TH-4 as a pale yellow gel $(61 \mathrm{mg}, 69 \%) .{ }^{1} \mathrm{H}$ NMR (500 MHz, Chloroform- $d$ ) $\delta 7.18(\mathrm{td}, J=5.1,1.2 \mathrm{~Hz}, 1 \mathrm{H}), 6.97-6.88(\mathrm{~m}, 2 \mathrm{H}), 6.55$ (ddd, $J=25.9,16.7,10.4 \mathrm{~Hz}, 1 \mathrm{H}), 6.38$ (ddd, $J=52.2,16.7,2.0 \mathrm{~Hz}, 1 \mathrm{H}), 5.72(\mathrm{ddd}, J=18.1,10.4,2.0 \mathrm{~Hz}, 1 \mathrm{H}), 4.57$ (dt, $J=13.6,3.6 \mathrm{~Hz}$, $1 \mathrm{H}$ ), 4.14 (ddd, $J=11.2,5.8,3.3 \mathrm{~Hz}, 1 \mathrm{H}$ ), 4.06 (dt, $J=14.4,3.9 \mathrm{~Hz}, 1 \mathrm{H}), 3.94-3.87$ (m, 1H), 3.79 (ddd, $J=15.6,9.9,5.2 \mathrm{~Hz}, 1 \mathrm{H}$ ), 3.24 (ddd, $J=13.6,11.3,3.8 \mathrm{~Hz}, 1 \mathrm{H}$ ), 3.01 (ddd, $J=15.2$, $11.3,4.0 \mathrm{~Hz}, 1 \mathrm{H}), 2.96-2.72(\mathrm{~m}, 2 \mathrm{H}), 2.59$ (ddt, $J=15.0,10.3,5.3 \mathrm{~Hz}, 1 \mathrm{H}), 2.33-2.18(\mathrm{~m}, 1 \mathrm{H})$; ${ }^{13} \mathrm{C}$ NMR (125 MHz, Chloroform- $d$ ) $\delta$ 166.32, 166.09, 145.40, 145.34, 129.03, 128.11, 127.46, $126.80,126.62,126.58,124.54,124.51,124.48,124.37,52.29,50.96,46.92,45.96,45.86,45.18$, 38.53, 36.17, 34.19, 33.29. HRMS (GC-EI-TOF) calculated for $\mathrm{C}_{12} \mathrm{H}_{15} \mathrm{NOS}_{2}{ }^{+}[\mathrm{M}]^{+}:$253.0595, observed 253.0595
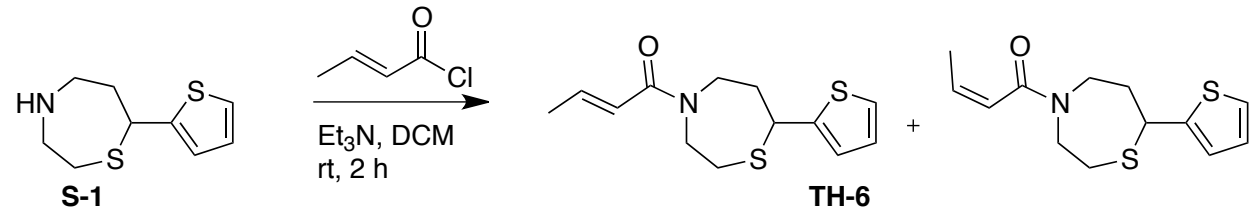

Compound S-1 (70 mg, $0.35 \mathrm{mmol}$ ) was dissolved in DCM (5 mL), along with crotonyl chloride ( $90 \%$ trans $10 \%$ cis) $(56 \mathrm{mg}, 0.53 \mathrm{mmol})$, and triethylamine $(98 \mu \mathrm{L}, 0.18 \mathrm{mmol})$ and the resulting solution was stirred at room temperature for $2 \mathrm{~h}$. Reaction was quenched with $\mathrm{H}_{2} \mathrm{O}(5 \mathrm{~mL})$ and 
further extracted with DCM $(3 \times 5 \mathrm{~mL})$. The combined organic layer was dried over $\mathrm{MgSO}_{4}$. The organic layer was filtered, concentrated, and purified on a Combiflash RF system (hexanes/EtOAc, $0-100 \%$ EtOAc) to afford compound TH-6 as a pale yellow gel $(11.0 \mathrm{mg}, 34 \%)$ and isolated as mixture of inseparable stereoisomers isomers $(\sim 30 \%$ sum of other minor species, mixture of configurational and rotational isomers). ${ }^{1} \mathrm{H}$ NMR $(500 \mathrm{MHz}$, Chloroform- $d$ ), only the major isomer is reported for clarity. $\delta 7.19(\mathrm{ddd}, J=8.4,5.1,1.1 \mathrm{~Hz}, 1 \mathrm{H}, 6.98-6.89(\mathrm{~m}, 3 \mathrm{H}), 6.24$ (ddd, $J=14.8,13.1,1.6 \mathrm{~Hz}, 1 \mathrm{H}), 4.13(\mathrm{dtt}, J=23.5,9.1,4.6 \mathrm{~Hz}, 2 \mathrm{H}), 4.01-3.89(\mathrm{~m}, 1 \mathrm{H}), 3.83-3.73$ (m, 1H), 3.67 (ddp, $J=13.2,9.0,4.3 \mathrm{~Hz}, 1 \mathrm{H}), 3.58-3.47$ (m, 1H), 3.19 (ddd, $J=13.6,11.4,3.7$ $\mathrm{Hz}, 1 \mathrm{H}), 3.08-2.75(\mathrm{~m}, 3 \mathrm{H}), 2.62$ (ddq, $J=15.4,10.4,5.2 \mathrm{~Hz}, 1 \mathrm{H}), 2.25$ (dddt, $J=14.4,11.5$, 6.5, $2.8 \mathrm{~Hz}, 1 \mathrm{H}), 1.90(\mathrm{dt}, J=6.9,1.7 \mathrm{~Hz}, 4 \mathrm{H}) ;{ }^{13} \mathrm{C}$ NMR $(125 \mathrm{MHz}$, Chloroform- $d$ ) $\delta 166.54$, $166.44,145.63,142.99,142.19,138.51,136.34,126.70,126.67,124.59,124.52,124.46,122.89$, $121.41,121.04,52.47,51.16,47.04,46.04(\mathrm{~d}, J=5.7 \mathrm{~Hz}), 45.31,44.90,38.60,36.43,34.50,33.68$, 18.32. HRMS (GC-EI-TOF) calculated for $\mathrm{C}_{13} \mathrm{H}_{17} \mathrm{NOS}_{2}{ }^{+}[\mathrm{M}]^{+}: 267.0752$, observed 267.0755.

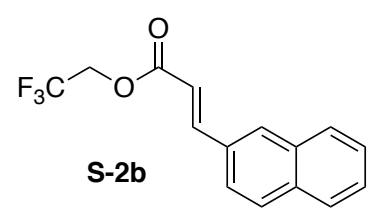

To a solution of 3-(2-Napthyl)acrylic acid (500 $\mathrm{mg}, 2.52 \mathrm{mmol})$ in DCM $(20 \mathrm{~mL})$ at room temperature was added EDCI-HCl $(725 \mathrm{mg}, 3.78 \mathrm{mmol})$, $\mathrm{Et}_{3} \mathrm{~N}$ (527 $\left.\mu \mathrm{L}, 3.78 \mathrm{mmol}\right)$, DMAP (31 $\left.\mathrm{mg}, 0.25 \mathrm{mmol}\right)$, and trifluoroethanol $(545 \mu \mathrm{L}, 7.57 \mathrm{mmol})$. The solution stirred at room temperature for $18 \mathrm{~h}$, at which point, the reaction was quenched with $\mathrm{H}_{2} \mathrm{O}$ $(5 \mathrm{~mL})$. Extracted with DCM $(3 \times 10 \mathrm{~mL})$, dried $\left(\mathrm{MgSO}_{4}\right)$, filtered and concentrated in vacuo. Purified by Combiflash RF system (hexanes/EtOAc, 0-100\% EtOAc). Isolated $560 \mathrm{mg}(79 \%)$ of S-2b as a white solid. ${ }^{1} \mathrm{H}$ NMR $\left(500 \mathrm{MHz}, \mathrm{CDCl}_{3}\right) \delta 7.99-7.92(\mathrm{~m}, 2 \mathrm{H}), 7.86(\mathrm{qd}, J=6.5,2.9$ $\mathrm{Hz}, 3 \mathrm{H}), 7.69$ (dd, $J=8.7,1.7 \mathrm{~Hz}, 1 \mathrm{H}), 7.54$ (hept, $J=5.2 \mathrm{~Hz}, 2 \mathrm{H}), 6.60$ (d, $J=16.0 \mathrm{~Hz}, 1 \mathrm{H}), 4.62$ $(\mathrm{q}, J=8.5 \mathrm{~Hz}, 2 \mathrm{H}) .{ }^{13} \mathrm{C}$ NMR $\left(126 \mathrm{MHz}, \mathrm{CDCl}_{3}\right) \delta 165.4,147.4,134.7,133.4,131.5,130.8$, $129.0,128.8,128.0,127.8,127.0,123.3(\mathrm{~d}, J=277.2 \mathrm{~Hz}), 116.2,60.6(\mathrm{q}, J=36.6 \mathrm{~Hz}) .{ }^{19} \mathrm{~F} \mathrm{NMR}$ $\left(471 \mathrm{MHz}, \mathrm{CDCl}_{3}\right) \delta-73.7(\mathrm{t}, J=8.6 \mathrm{~Hz})$. HRMS (GC-EI-TOF) calculated for $\mathrm{C}_{15} \mathrm{H}_{11} \mathrm{~F}_{3} \mathrm{O}_{2}{ }^{+}[\mathrm{M}]^{+}$: 280.0706, observed 280.0695 .

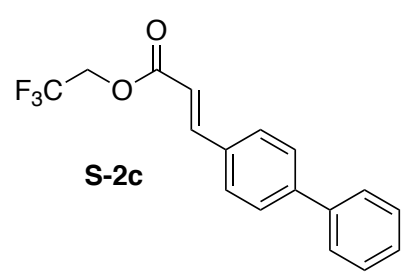

To a solution of 4-phenylcinnamic acid (500 $\mathrm{mg}, 2.23 \mathrm{mmol})$ in DCM $(20 \mathrm{~mL})$ at room temperature was added EDCI-HCl $(641 \mathrm{mg}, 3.35$ mmol), Et $3 \mathrm{~N}(466 \mu \mathrm{L}, 3.35 \mathrm{mmol})$, DMAP $(27 \mathrm{mg}, 0.22 \mathrm{mmol})$, and trifluoroethanol $(482 \mu \mathrm{L}, 6.69 \mathrm{mmol})$. The solution stirred at room temperature for $18 \mathrm{~h}$, at which point, the reaction was quenched with $\mathrm{H}_{2} \mathrm{O}(5 \mathrm{~mL})$. Extracted with DCM $(3 \times 10 \mathrm{~mL})$, dried $\left(\mathrm{MgSO}_{4}\right)$, filtered and concentrated in vacuo. Purified by Combiflash RF system (hexanes/EtOAc, 0-100\% EtOAc). Isolated $491 \mathrm{mg}(72 \%)$ of $\mathbf{S - 2 c}$ as a white solid. ${ }^{1} \mathrm{H}$ NMR $\left(400 \mathrm{MHz}, \mathrm{CDCl}_{3}\right) \delta 7.83(\mathrm{~d}, J=16.0$ $\mathrm{Hz}, 1 \mathrm{H}), 7.69-7.56(\mathrm{~m}, 6 \mathrm{H}), 7.47$ (t, $J=7.5 \mathrm{~Hz}, 2 \mathrm{H}), 7.41-7.37$ (m, 1H), 6.53 (d, $J=16.0 \mathrm{~Hz}$, $1 \mathrm{H}), 4.61(\mathrm{q}, J=8.5 \mathrm{~Hz}, 2 \mathrm{H}) .{ }^{13} \mathrm{C}$ NMR $\left(101 \mathrm{MHz}, \mathrm{CDCl}_{3}\right) \delta 165.4,146.9,143.9,140.1,133.0$, $129.1,129.0,128.2,127.8,127.2,123.3(\mathrm{q}, J=277.2 \mathrm{~Hz}), 115.8,60.6(\mathrm{q}, J=36.7 \mathrm{~Hz}) .{ }^{19} \mathrm{~F}$ NMR $\left(471 \mathrm{MHz}, \mathrm{CDCl}_{3}\right) \delta-73.7(\mathrm{t}, J=8.5 \mathrm{~Hz})$. HRMS (GC-EI-TOF) calculated for $\mathrm{C}_{15} \mathrm{H}_{11} \mathrm{~F}_{3} \mathrm{O}_{2}{ }^{+}[\mathrm{M}]^{+}$: 306.0862, observed 306.0849. 


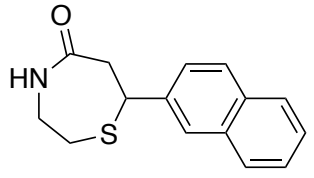

S-3b

To a solution of $\mathbf{S - 2 b}(250 \mathrm{mg}, 0.893 \mathrm{mmol})$ in $\mathrm{MeCN}(9.0 \mathrm{~mL})$ at room temperature was added DBU $(320 \mu \mathrm{L}, 2.14)$ and cysteamine hydrochloride (122 mg, $1.07 \mathrm{mmol}$ ). The solution stirred at room temperature for $18 \mathrm{~h}$ before it was quenched with $\mathrm{H}_{2} \mathrm{O}(4 \mathrm{~mL})$. Extracted with EtOAc $(3 \times 5 \mathrm{~mL})$, dried $\left(\mathrm{MgSO}_{4}\right)$, filtered in vacuo and concentrated. Purified by Combiflash RF system (hexanes/EtOAc, $0-100 \%$ EtOAc). Isolated $128 \mathrm{mg}(56 \%)$ of $\mathbf{S - 3 b}$ as an off-white solid and mixture of rotational isomers. H NMR (500 MHz, $\left.\mathrm{CDCl}_{3}\right) \delta 7.87-7.74(\mathrm{~m}, 4 \mathrm{H}), 7.53-7.41(\mathrm{~m}, 3 \mathrm{H}), 7.04(\mathrm{~s}, 1 \mathrm{H}), 4.33$ $(\mathrm{d}, J=10.3 \mathrm{~Hz}, 1 \mathrm{H}), 4.02-3.55(\mathrm{~m}, 4 \mathrm{H}), 3.16$ (dd, $J=13.9,1.4 \mathrm{~Hz}, 1 \mathrm{H}), 3.06$ (ddd, $J=14.8$, 10.0, $1.6 \mathrm{~Hz}, 1 \mathrm{H}), 2.85-2.67(\mathrm{~m}, 1 \mathrm{H}) .{ }^{13} \mathrm{C} \mathrm{NMR}\left(126 \mathrm{MHz}, \mathrm{CDCl}_{3}\right) \delta 176.4,139.0,133.4,133.0$, 128.8, 128.1, 127.8, 126.5, 126.4, 126.0, 125.3, 47.6, 45.9, 42.8, 33.4. HRMS (GC-EI-TOF) calculated for $\mathrm{C}_{15} \mathrm{H}_{15} \mathrm{NOS}^{+}[\mathrm{M}]^{+}:$257.0869, observed 257.0869 .

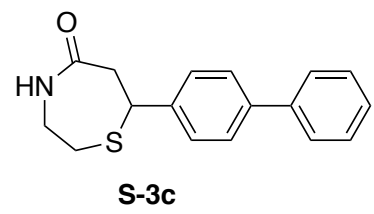

To a solution of S-2c (250 mg, $0.817 \mathrm{mmol})$ in $\mathrm{MeCN}(8.0 \mathrm{~mL})$ at room temperature was added DBU $(293 \mu \mathrm{L}, 1.96)$ and cysteamine hydrochloride $(111 \mathrm{mg}, 0.980 \mathrm{mmol})$. The solution stirred at room temperature for $18 \mathrm{~h}$ before it was quenched with $\mathrm{H}_{2} \mathrm{O}(4 \mathrm{~mL})$. Extracted with EtOAc $(3 \times 5$ $\mathrm{mL})$, dried $\left(\mathrm{MgSO}_{4}\right)$, filtered in vacuo and concentrated. Purified by Combiflash RF system (hexanes/EtOAc, 0-100\% EtOAc). Isolated $135 \mathrm{mg}$ (58\%) of $\mathbf{S - 3 c}$ as an off-white solid and mixture of rotational isomers. ${ }^{1} \mathrm{H}$ NMR $\left(500 \mathrm{MHz}, \mathrm{CDCl}_{3}\right) \delta 7.62-7.52(\mathrm{~m}$, $4 \mathrm{H}), 7.48-7.38(\mathrm{~m}, 4 \mathrm{H}), 7.38-7.31(\mathrm{~m}, 1 \mathrm{H}), 6.98(\mathrm{~s}, 1 \mathrm{H}), 4.21(\mathrm{dd}, J=10.5,1.2 \mathrm{~Hz}, 1 \mathrm{H}), 3.80$ $(\mathrm{ddd}, J=14.9,9.9,4.7 \mathrm{~Hz}, 1 \mathrm{H}), 3.74-3.64(\mathrm{~m}, 1 \mathrm{H}), 3.58(\mathrm{dd}, J=13.9,10.4 \mathrm{~Hz}, 1 \mathrm{H}), 3.10$ (dd, $J$ $=13.9,1.3 \mathrm{~Hz}, 1 \mathrm{H}), 3.03(\mathrm{ddd}, J=14.8,10.0,1.6 \mathrm{~Hz}, 1 \mathrm{H}), 2.73(\mathrm{ddd}, J=14.8,6.4,1.3 \mathrm{~Hz}, 1 \mathrm{H})$. ${ }^{13} \mathrm{C} \mathrm{NMR}\left(126 \mathrm{MHz}, \mathrm{CDCl}_{3}\right) \delta 176.2,140.9,140.7,140.6,128.9,127.6,127.6,127.6,127.2,47.6$, 45.8, 42.3, 33.4. HRMS (GC-EI-TOF) calculated for $\mathrm{C}_{17} \mathrm{H}_{17} \mathrm{NOS}^{+}[\mathrm{M}]^{+}:$283.1025, observed 283.1021 .

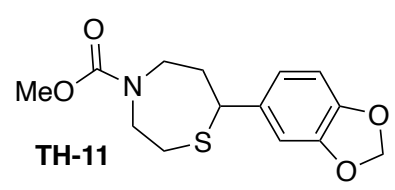

To a solution of thiazepanone $\mathbf{S - 3 a}(90 \mathrm{mg}, 0.358 \mathrm{mmol})$ and $\mathrm{NaBH}_{4}(47$ $\mathrm{mg}, 1.79 \mathrm{mmol})$ in $\mathrm{THF}(1.5 \mathrm{~mL})$ at $0{ }^{\circ} \mathrm{C}$ was added $\mathrm{I}_{2}(182 \mathrm{mg}, 0.717$ $\mathrm{mmol})$ in THF $(1.5 \mathrm{~mL})$ dropwise via addition funnel. It was then heated to $60{ }^{\circ} \mathrm{C}$ for $45 \mathrm{~min}$ before being cooled to room temperature. $0.1 \mathrm{~N} \mathrm{HCl}$ was added until the solution became transparent and no long produced bubbles. It was then partially concentrated in vacuo before it was redissolved in $\mathrm{MeOH}(2.0 \mathrm{~mL})$ and $6 \mathrm{~N} \mathrm{HCl}(2.0 \mathrm{~mL})$ and heated to $60{ }^{\circ} \mathrm{C}$ for $30 \mathrm{~min}$. Organic solvent was then partially removed in vacuo before extraction was EtOAc $(3 \times 3 \mathrm{~mL})$. The $\mathrm{pH}$ was then adjusted to 14 with solid $\mathrm{NaOH}$. Product was then extracted with EtOAc $(3 \times 5 \mathrm{~mL})$. Both sets of organic extracts were combined, dried $\left(\mathrm{MgSO}_{4}\right)$, filtered and concentrated in vacuo. The resultant crude amine was redissolved in DCM $(3.0 \mathrm{~mL})$ before the addition of $\mathrm{Et}_{3} \mathrm{~N}(24 \mathrm{~mL}, 0.172 \mathrm{mmol})$ and methyl chloroformate $(19 \mathrm{~mL}, 0.175 \mathrm{mmol})$ at room temperature. The solution stirred for $30 \mathrm{~min}$ and was monitored by TLC. Upon completion, the reaction was quenched with $\mathrm{H}_{2} \mathrm{O}(3 \mathrm{~mL})$ and extracted from the aqueous layer $(3 \times 3 \mathrm{~mL})$. The organic extracts were then dried $\left(\mathrm{MgSO}_{4}\right)$, filtered and concentrated in vacuo. Purified on a Combiflash RF system (hexanes/EtOAc, 0-100\% EtOAc). 
Isolated $23 \mathrm{mg}(41 \%)$ of $\mathbf{T H}-11$ as a yellow oil containing a mixture of rotational isomers. ${ }^{1} \mathrm{H}$ NMR $\left(500 \mathrm{MHz}, \mathrm{CDCl}_{3}\right) \delta 6.79(\mathrm{dd}, J=6.0,1.8 \mathrm{~Hz}, 1 \mathrm{H}), 6.78-6.69(\mathrm{~m}, 2 \mathrm{H}), 5.93(\mathrm{~d}, J=2.2$ $\mathrm{Hz}, 2 \mathrm{H}), 4.14$ (ddd, $J=13.9,4.3,2.5 \mathrm{~Hz}, 0.5 \mathrm{H}), 3.96$ (ddd, $J=14.0,4.3,2.6 \mathrm{~Hz}, 0.5 \mathrm{H}), 3.78-$ $3.70(\mathrm{~m}, 4 \mathrm{H}), 3.70-3.51(\mathrm{~m}, 2 \mathrm{H}), 3.42(\mathrm{dddd}, J=37.0,13.9,11.6,4.3 \mathrm{~Hz}, 1 \mathrm{H}), 3.00-2.84(\mathrm{~m}$, $1 \mathrm{H}), 2.81$ (ddd, $J=14.7,4.3,2.5 \mathrm{~Hz}, 1 \mathrm{H}), 2.52-2.34(\mathrm{~m}, 1 \mathrm{H}), 2.20-2.01(\mathrm{~m}, 1 \mathrm{H}) .{ }^{13} \mathrm{C}$ NMR $(126$ $\left.\mathrm{MHz}_{\mathrm{CDCl}}\right) \delta 157.0,156.6,141.8,141.7,140.9,140.4,140.3,128.9,128.9,127.6,127.6,127.5$, $127.4,127.2,52.9,52.9,51.8,51.7,51.6,51.1,46.8,46.5,37.9,37.4,34.8,34.8$. HRMS (GC-EITOF) calculated for $\mathrm{C}_{14} \mathrm{H}_{17} \mathrm{NO}_{4} \mathrm{~S}^{+}[\mathrm{M}]^{+}: 295.0873$, observed 295.0871.

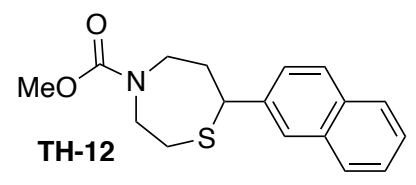

To a solution of amide S-3b (119 $\mathrm{mg}, 0.423 \mathrm{mmol})$ and $\mathrm{NaBH}_{4}(55 \mathrm{mg}$, $2.12 \mathrm{mmol})$ in THF $(2.0 \mathrm{~mL})$ was added $\mathrm{I}_{2}(215 \mathrm{mg}, 0.846 \mathrm{mmol})$ in THF $(2.0 \mathrm{~mL})$ dropwise via addition funnel. It was then heated to $60{ }^{\circ} \mathrm{C}$ for $45 \mathrm{~min}$ before being cooled to room temperature. $0.1 \mathrm{~N} \mathrm{HCl}$ was added until the solution became transparent and no long produced bubbles. It was then partially concentrated in vacuo before it was redissolved in $\mathrm{MeOH}(2.0 \mathrm{~mL})$ and $6 \mathrm{~N} \mathrm{HCl}(2.0 \mathrm{~mL})$ and heated to $60{ }^{\circ} \mathrm{C}$ for $30 \mathrm{~min}$. Organic solvent was then partially removed in vacuo before extraction was EtOAc $(3 \times 3 \mathrm{~mL})$. The $\mathrm{pH}$ was then adjusted to 14 with solid $\mathrm{NaOH}$. Product was then extracted with EtOAc $(3 \times 5 \mathrm{~mL})$. Both sets of organic extracts were combined, dried $\left(\mathrm{MgSO}_{4}\right)$, filtered and concentrated in vacuo. The resultant crude amine was redissolved in DCM (3.0 mL) before the addition of $\mathrm{Et}_{3} \mathrm{~N}(77 \mu \mathrm{L}, 0.552 \mathrm{mmol})$ and methyl chloroformate $(46 \mathrm{~mL}, 0.598 \mathrm{mmol})$ at room temperature. The solution stirred for $30 \mathrm{~min}$ and was monitored by TLC. Upon completion, the reaction was quenched with $\mathrm{H}_{2} \mathrm{O}(3 \mathrm{~mL})$ and extracted from the aqueous layer $(3 \times 3 \mathrm{~mL})$. The organic extracts were then dried $\left(\mathrm{MgSO}_{4}\right)$, filtered and concentrated in vacuo. Purified on a Combiflash RF system (hexanes/EtOAc, 0-100\% EtOAc). Isolated $60 \mathrm{mg}(43 \%)$ of $\mathbf{T H}-12$ as a yellow oil containing a mixture of rotational isomers. ${ }^{1} \mathrm{H}$ NMR $\left(500 \mathrm{MHz}, \mathrm{CDCl}_{3}\right) \delta 7.84-7.77$ $(\mathrm{m}, 3 \mathrm{H}), 7.75(\mathrm{dd}, J=10.5,1.8 \mathrm{~Hz}, 1 \mathrm{H}), 7.46(\mathrm{pt}, J=4.8,2.2 \mathrm{~Hz}, 3 \mathrm{H}), 4.22-4.18(\mathrm{~m}, 0.5 \mathrm{H}), 4.02$ -3.95 (m, 1.5H), 3.78 (s, 3H), $3.76-3.56(\mathrm{~m}, 2 \mathrm{H}), 3.47$ (dddd, $J=40.6,13.8,11.5,4.2 \mathrm{~Hz}, 1 \mathrm{H})$, 2.98 (dddd, $J=34.8,15.4,11.5,4.2 \mathrm{~Hz}, 1 \mathrm{H}), 2.85$ (dtd, $J=14.8,4.4,2.6 \mathrm{~Hz}, 1 \mathrm{H}), 2.64-2.47$ (m, $1 \mathrm{H}), 2.41-2.21(\mathrm{~m}, 1 \mathrm{H}) .{ }^{13} \mathrm{C} \mathrm{NMR}\left(126 \mathrm{MHz}, \mathrm{CDCl}_{3}\right) \delta 157.0,156.5,140.0,139.9,133.5,132.7$, $128.6,128.5,127.9,127.9,127.7,127.7,126.3,126.3,126.0,125.9,125.9,125.9,125.4,125.3$, 52.9, 52.8, 52.0, 51.9, 51.7, 51.1, 46.8, 46.5, 37.7, 37.2, 34.7, 34.7. HRMS (GC-EI-TOF) calculated for $\mathrm{C}_{17} \mathrm{H}_{19} \mathrm{NO}_{2} \mathrm{~S}^{+}[\mathrm{M}]^{+}: 301.1131$, observed 301.1131 .

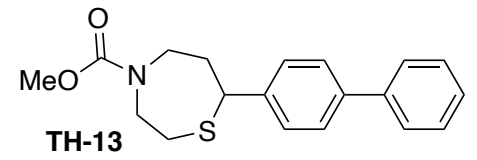

To a solution of thiazepanone $\mathbf{S - 3 c}(70 \mathrm{mg}, 0.247 \mathrm{mmol})$ and $\mathrm{NaBH}_{4}$ $(32 \mathrm{mg}, 1.24 \mathrm{mmol})$ in THF $(2.0 \mathrm{~mL})$ at $0{ }^{\circ} \mathrm{C}$ was added $\mathrm{I}_{2}(126 \mathrm{mg}$, $0.495 \mathrm{mmol})$ in THF $(2.0 \mathrm{~mL})$ dropwise via addition funnel. It was then heated to $60{ }^{\circ} \mathrm{C}$ for $45 \mathrm{~min}$ before being cooled to room temperature. $0.1 \mathrm{~N} \mathrm{HCl}$ was added until the solution became transparent and no long produced bubbles. It was then partially concentrated in vacuo before it was redissolved in $\mathrm{MeOH}(2.0 \mathrm{~mL})$ and $6 \mathrm{~N} \mathrm{HCl}(2.0 \mathrm{~mL})$ and heated to $60{ }^{\circ} \mathrm{C}$ for $30 \mathrm{~min}$. Organic solvent was then partially removed in vacuo before extraction was EtOAc $(3 \times 3 \mathrm{~mL})$. The $\mathrm{pH}$ was then adjusted to 14 with solid $\mathrm{NaOH}$. Product was then extracted with EtOAc $(3 \times 5 \mathrm{~mL})$. Both sets of organic extracts were combined, dried $\left(\mathrm{MgSO}_{4}\right)$, filtered and concentrated in vacuo. The resultant crude amine was redissolved in DCM $(3.0 \mathrm{~mL})$ before the addition of $\mathrm{Et}_{3} \mathrm{~N}(13 \mathrm{~mL}, 0.0 .094 \mathrm{mmol})$ and methyl chloroformate $(10 \mathrm{~mL}, 0.101 \mathrm{mmol})$ at room temperature. The solution stirred for $30 \mathrm{~min}$ and was 
monitored by TLC. Upon completion, the reaction was quenched with $\mathrm{H}_{2} \mathrm{O}(3 \mathrm{~mL})$ and extracted from the aqueous layer $(3 \times 3 \mathrm{~mL})$. The organic extracts were then dried $\left(\mathrm{MgSO}_{4}\right)$, filtered and concentrated in vacuo. Purified on a Combiflash RF system (hexanes/EtOAc, 0-100\% EtOAc). Isolated $12 \mathrm{mg}(15 \%)$ of $\mathbf{T H}-13$ as a yellow oil containing a mixture of rotational isomers. ${ }^{1} \mathrm{H}$ NMR (500 MHz, $\left.\mathrm{CDCl}_{3}\right) \delta 7.63-7.50(\mathrm{~m}, 4 \mathrm{H}), 7.43(\mathrm{td}, J=7.7,1.8 \mathrm{~Hz}, 2 \mathrm{H}), 7.39-7.30(\mathrm{~m}$, $3 \mathrm{H}), 4.19$ (ddd, $J=13.9,4.2,2.5 \mathrm{~Hz}, 0.5 \mathrm{H}), 4.01$ (ddd, $J=14.1,4.2,2.7 \mathrm{~Hz}, 0.5 \mathrm{H}), 3.86$ (ddd, $J=$ 11.7, 6.6, $4.5 \mathrm{~Hz}, 1 \mathrm{H}), 3.77$ (s, 3H), $3.74-3.58$ (m, 2H), 3.49 (ddd, $J=14.0,11.4,4.4 \mathrm{~Hz}, 0.5 \mathrm{H}$ ), $3.41(\mathrm{ddd}, J=13.9,11.7,4.1 \mathrm{~Hz}, 0.5 \mathrm{H}), 3.04-2.90(\mathrm{~m}, 1 \mathrm{H}), 2.85(\mathrm{ddd}, J=14.7,4.2,2.6 \mathrm{~Hz}, 1 \mathrm{H})$, $2.67-2.39(\mathrm{~m}, 1 \mathrm{H}), 2.30-2.12(\mathrm{~m}, 1 \mathrm{H}) .{ }^{13} \mathrm{C} \mathrm{NMR}\left(126 \mathrm{MHz}, \mathrm{CDCl}_{3}\right) \delta 157.0,156.6,141.8$, $141.7,140.9,140.4,140.3,128.9,128.9,127.6,127.6,127.5,127.4,127.4,127.2,52.9,52.9,51.8$, 51.7, 51.6, 51.1, 46.8, 46.5, 37.9, 37.4, 34.8. HRMS (GC-EI-TOF) calculated for $\mathrm{C}_{19} \mathrm{H}_{21} \mathrm{NO}_{2}{ }^{+}$ $[\mathrm{M}]^{+}: 327.1288$, observed 327.1291 .

\section{${ }^{1} \mathrm{H}, \mathrm{CDCl}_{3}, 500 \mathrm{MHz}$ of $\mathbf{T H}-4$}

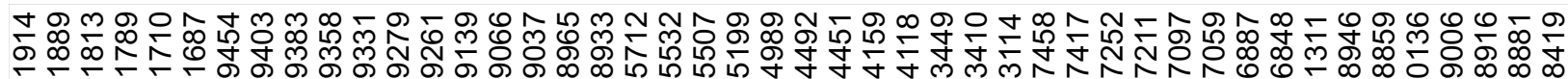

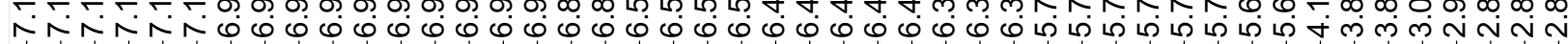

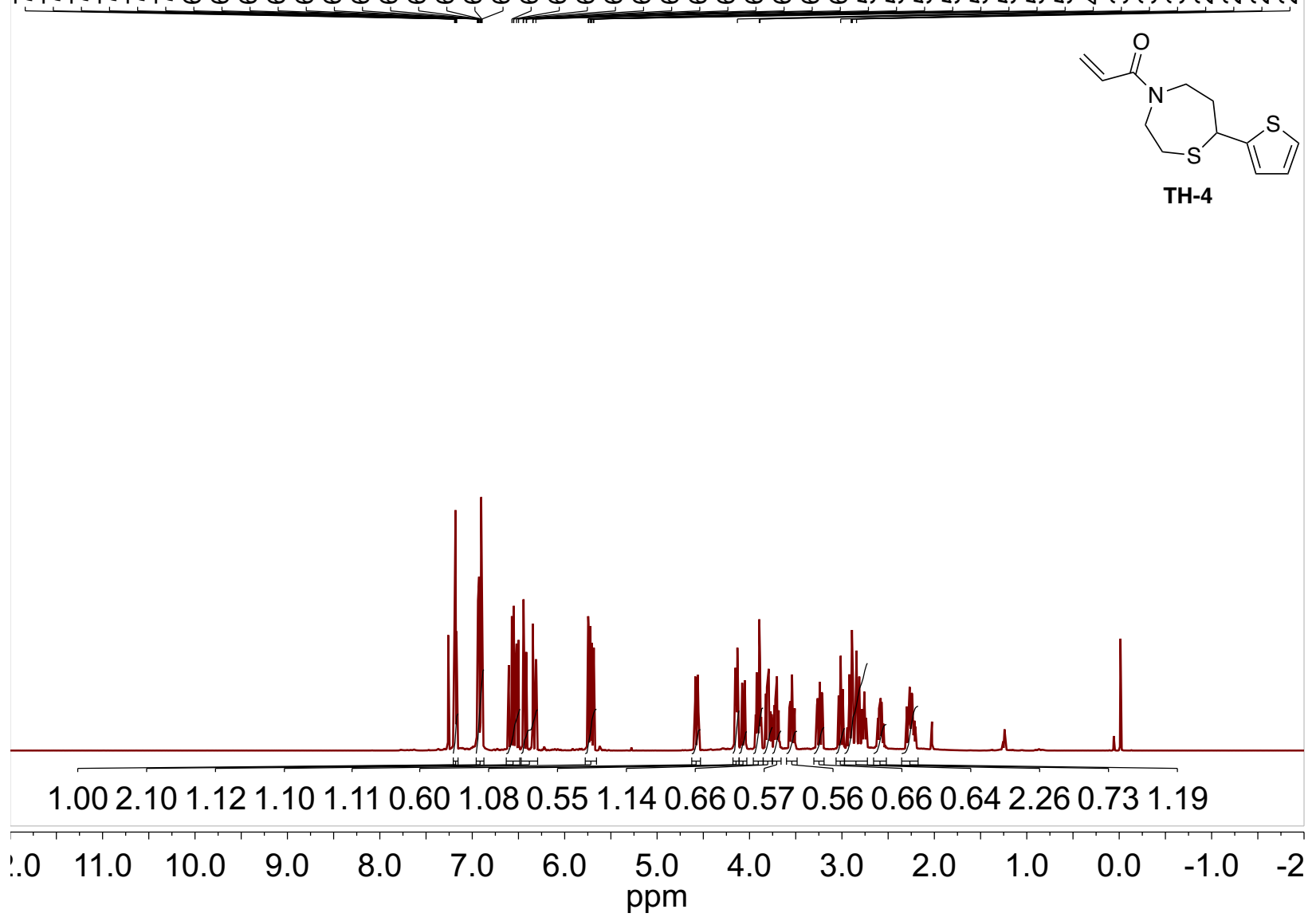


${ }^{13} \mathrm{C}, \mathrm{CDCl}_{3}, 125 \mathrm{MHz}$ of $\mathbf{T H}-4$

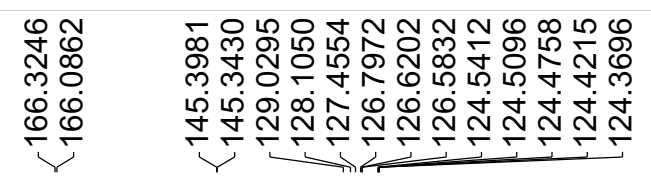

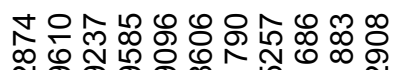

N के के क

ஸ̂ं
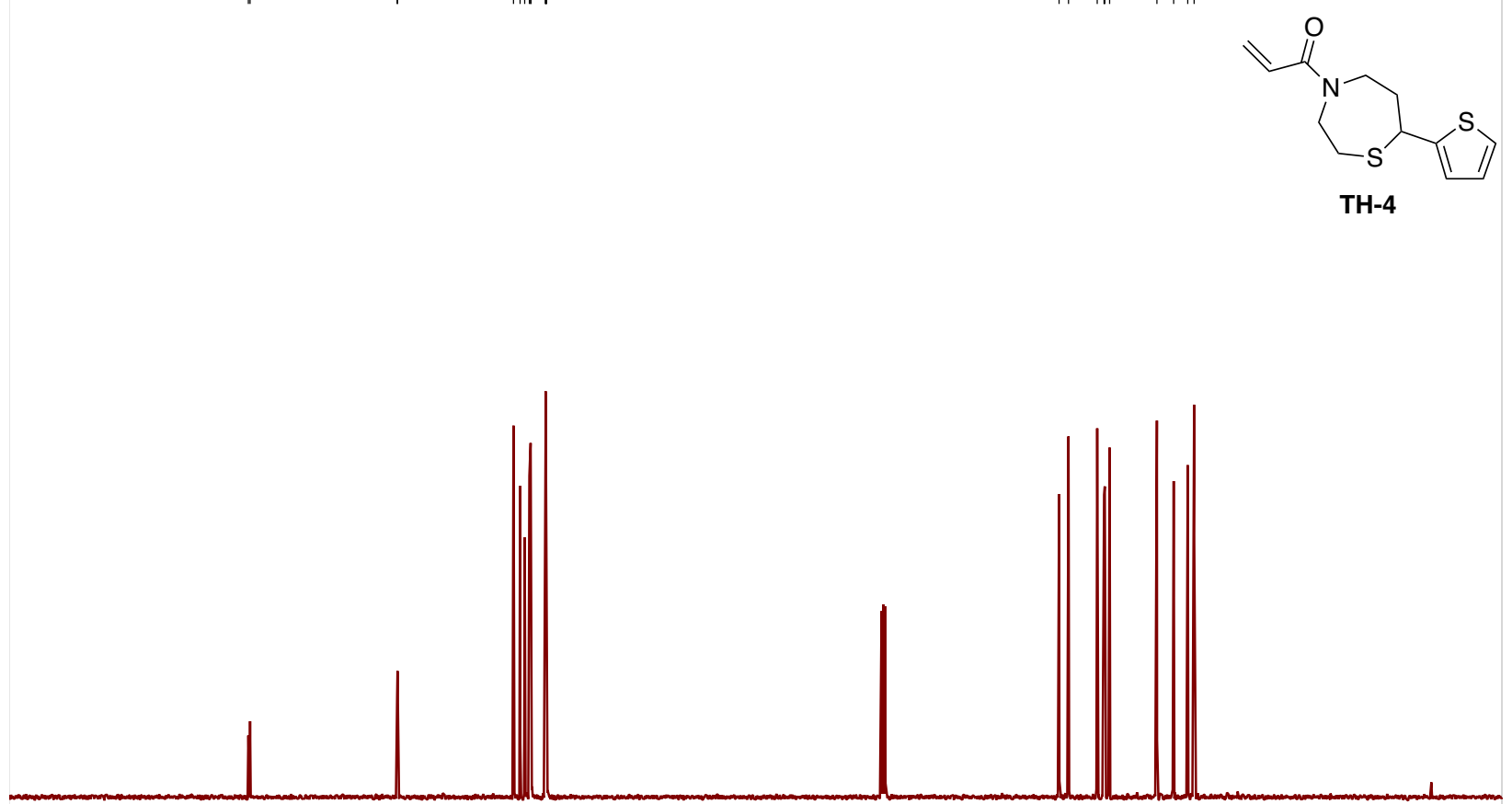

\begin{tabular}{lllllllllll}
\hline 190 & 170 & 150 & 130 & 110 & $\begin{array}{c}90 \\
\mathrm{ppm}\end{array}$ & 70 & 50 & 30 & 10 & -1
\end{tabular}




\section{${ }^{1} \mathrm{H}, \mathrm{CDCl}_{3}, 500 \mathrm{MHz}$ of TH-6}

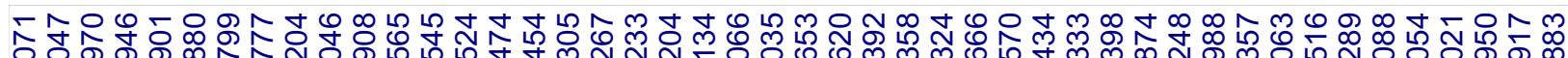

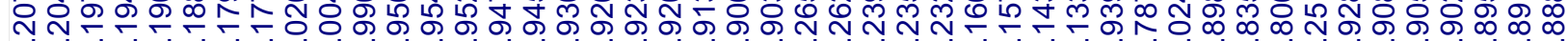
r r r r r r tre

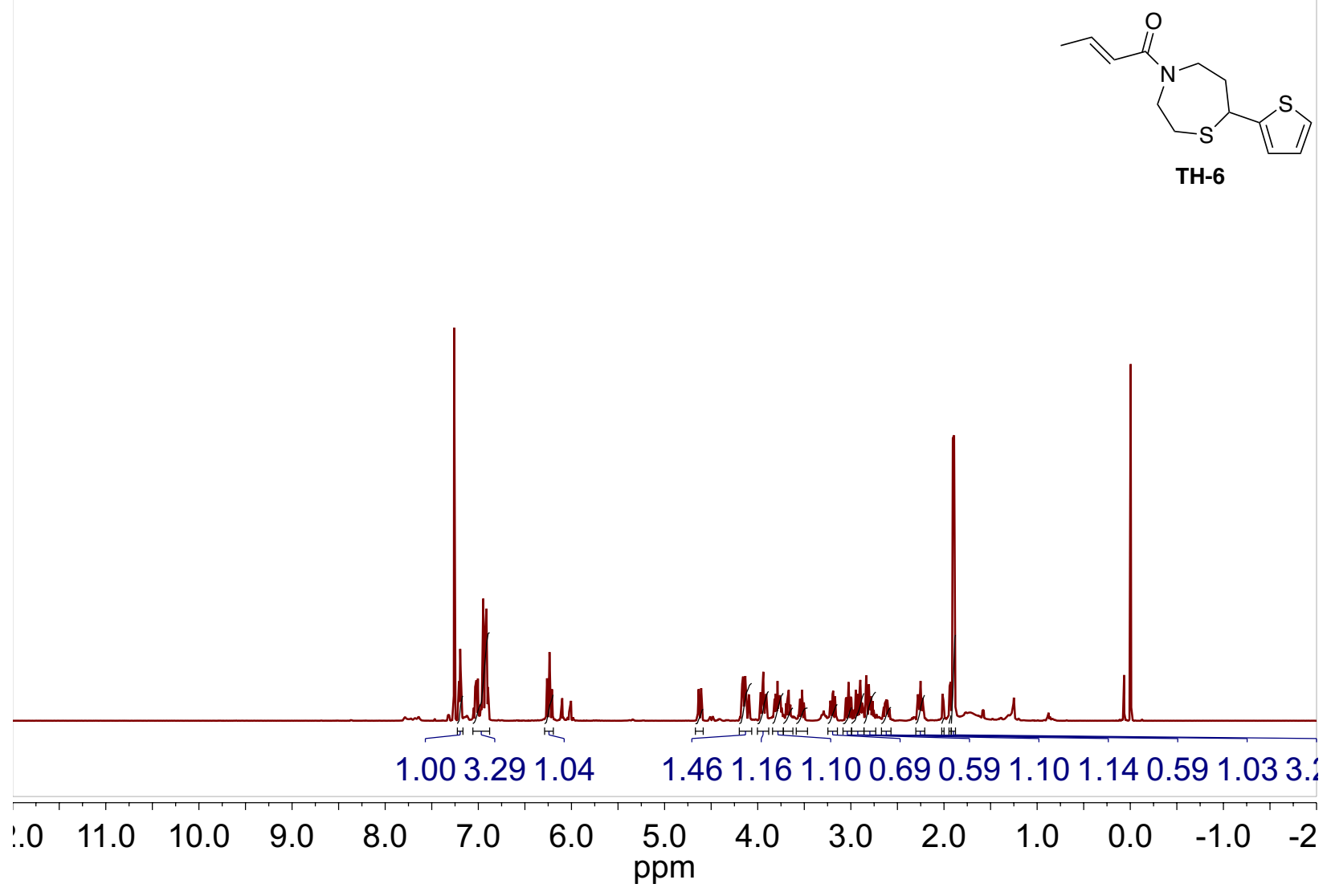


${ }^{13} \mathrm{C}, \mathrm{CDCl}_{3}, 125 \mathrm{MHz}$ of TH-6

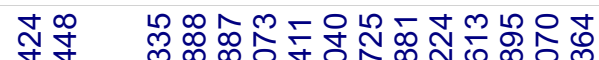

पे

它

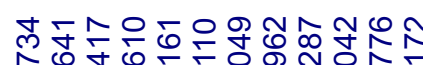
子 त̂ं

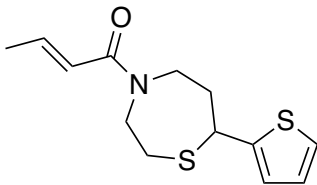

TH-6

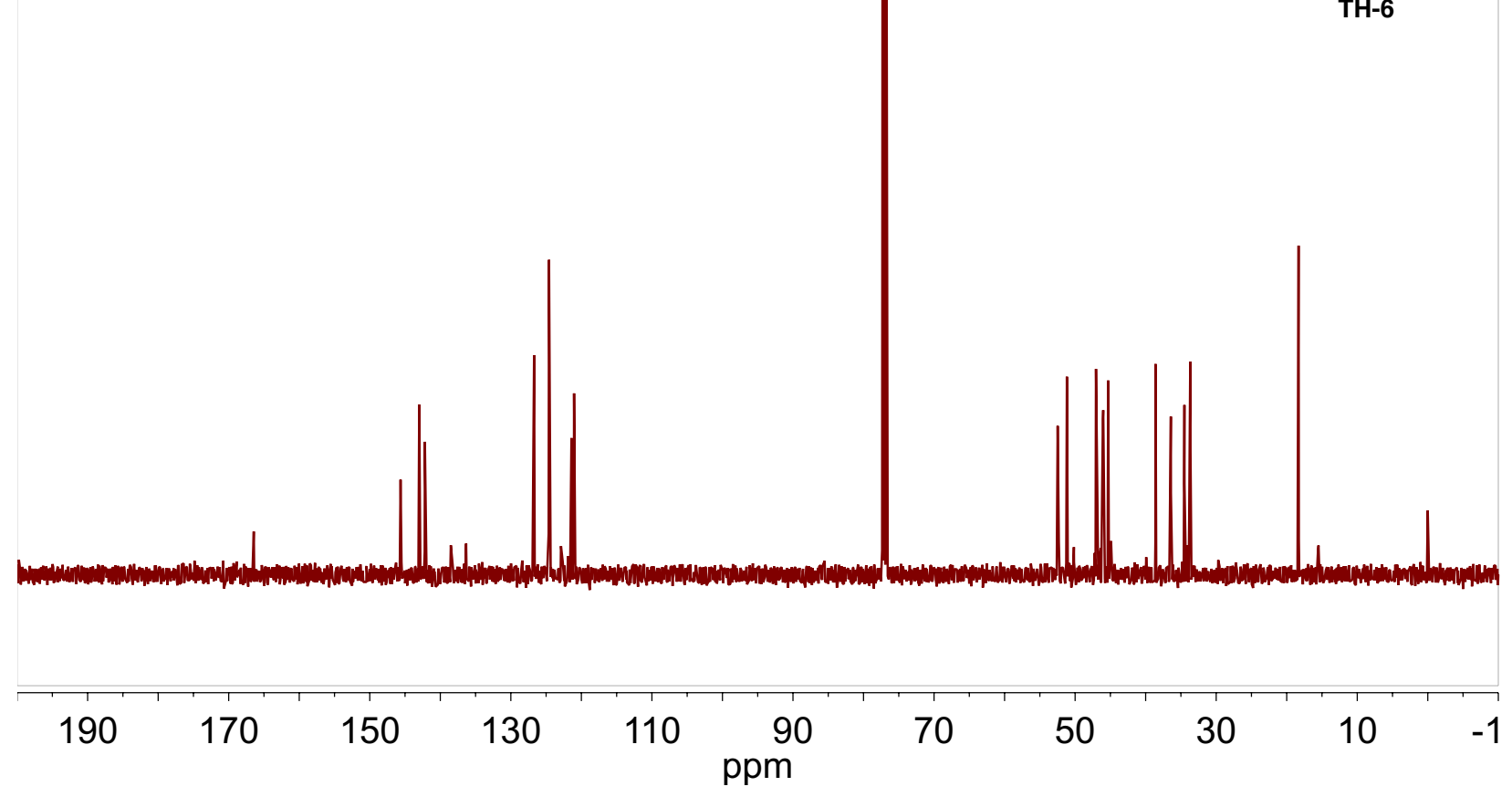


${ }^{1} \mathrm{H}, \mathrm{CDCl}_{3}, 500 \mathrm{MHz}$ of $\mathbf{S - 2 b}$

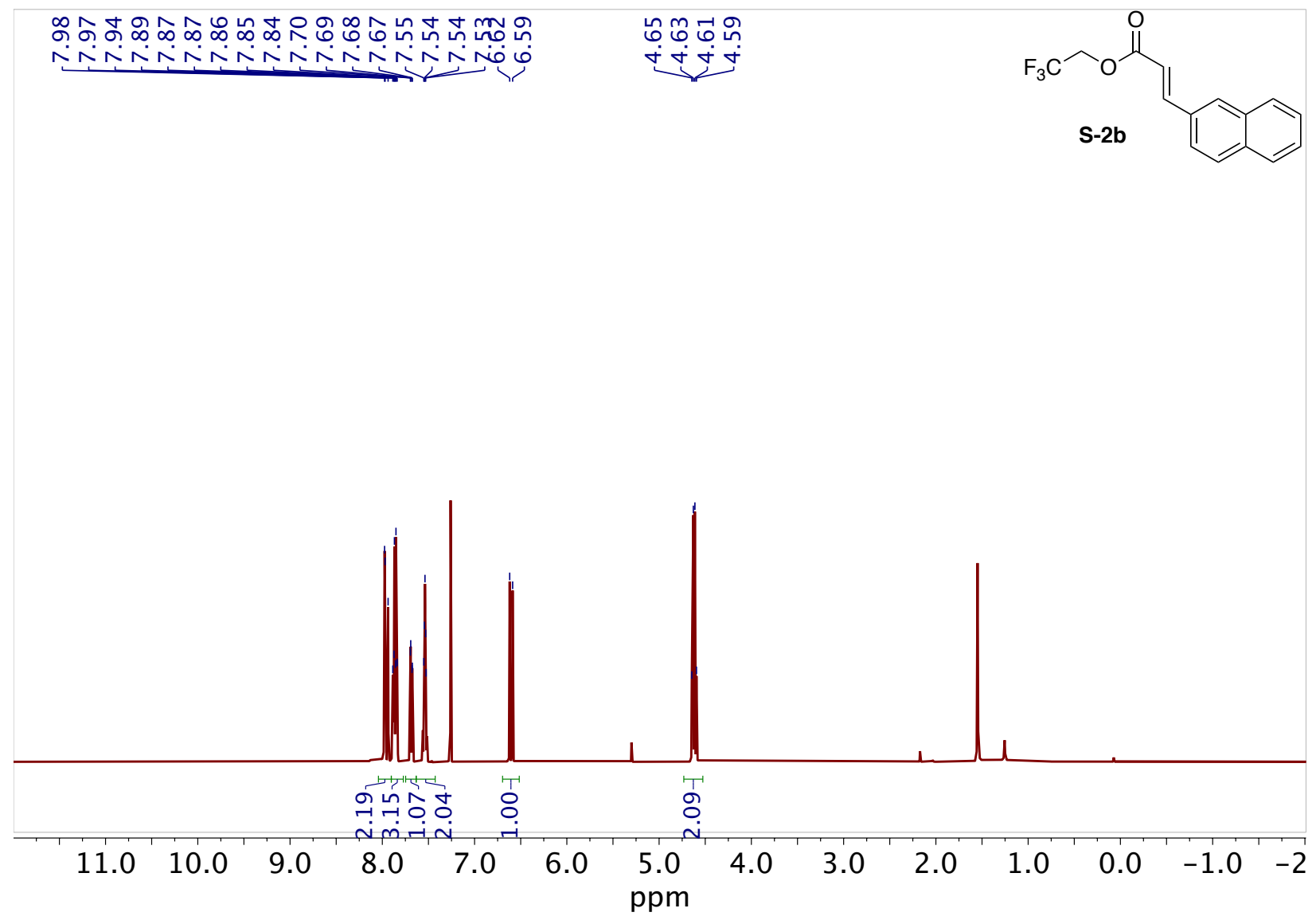


${ }^{13} \mathrm{C}, \mathrm{CDCl}_{3}, 125 \mathrm{MHz}$ of $\mathbf{S - 2 b}$

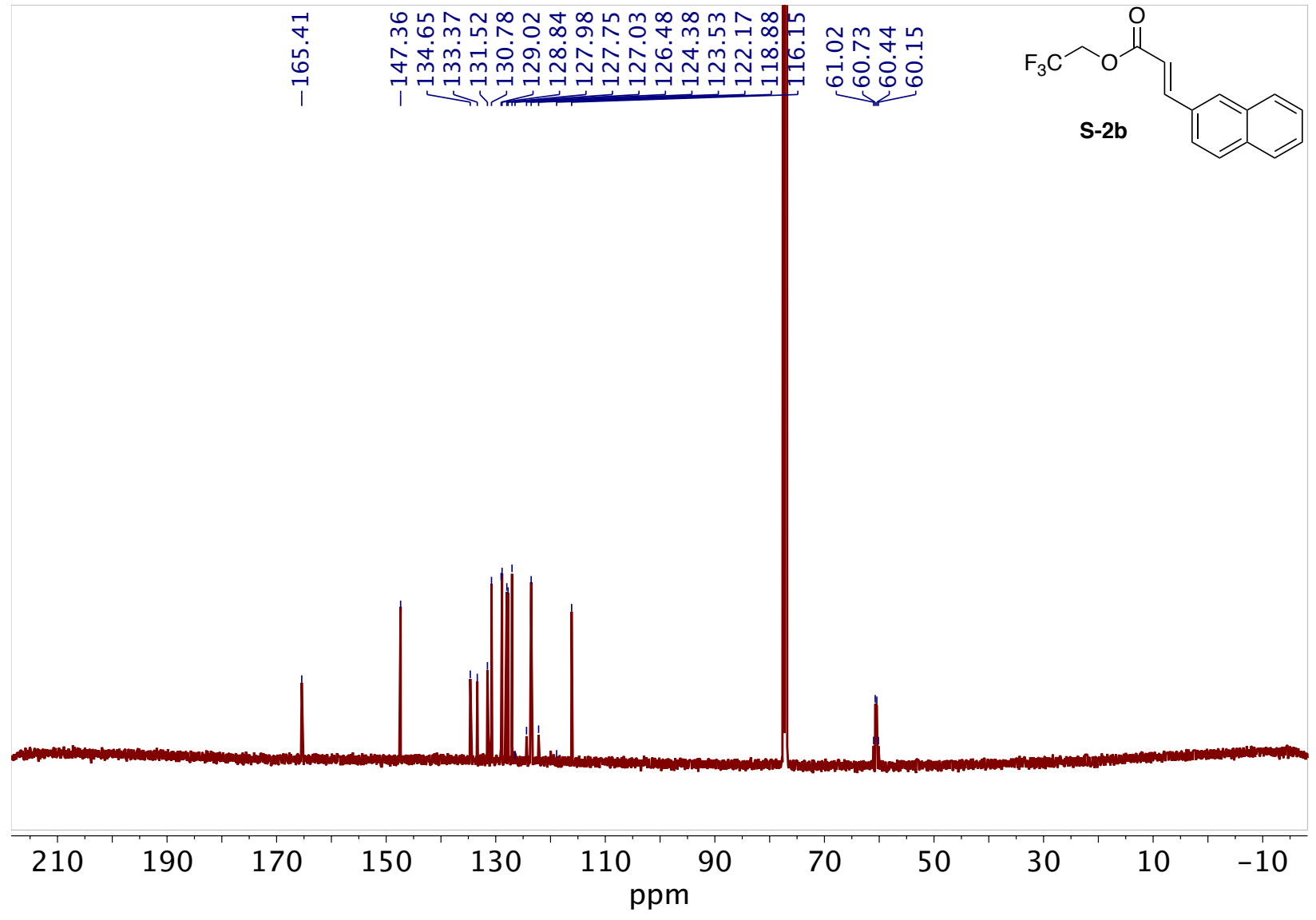


${ }^{1} \mathrm{H}, \mathrm{CDCl}_{3}, 500 \mathrm{MHz}$ of $\mathbf{S - 2 c}$

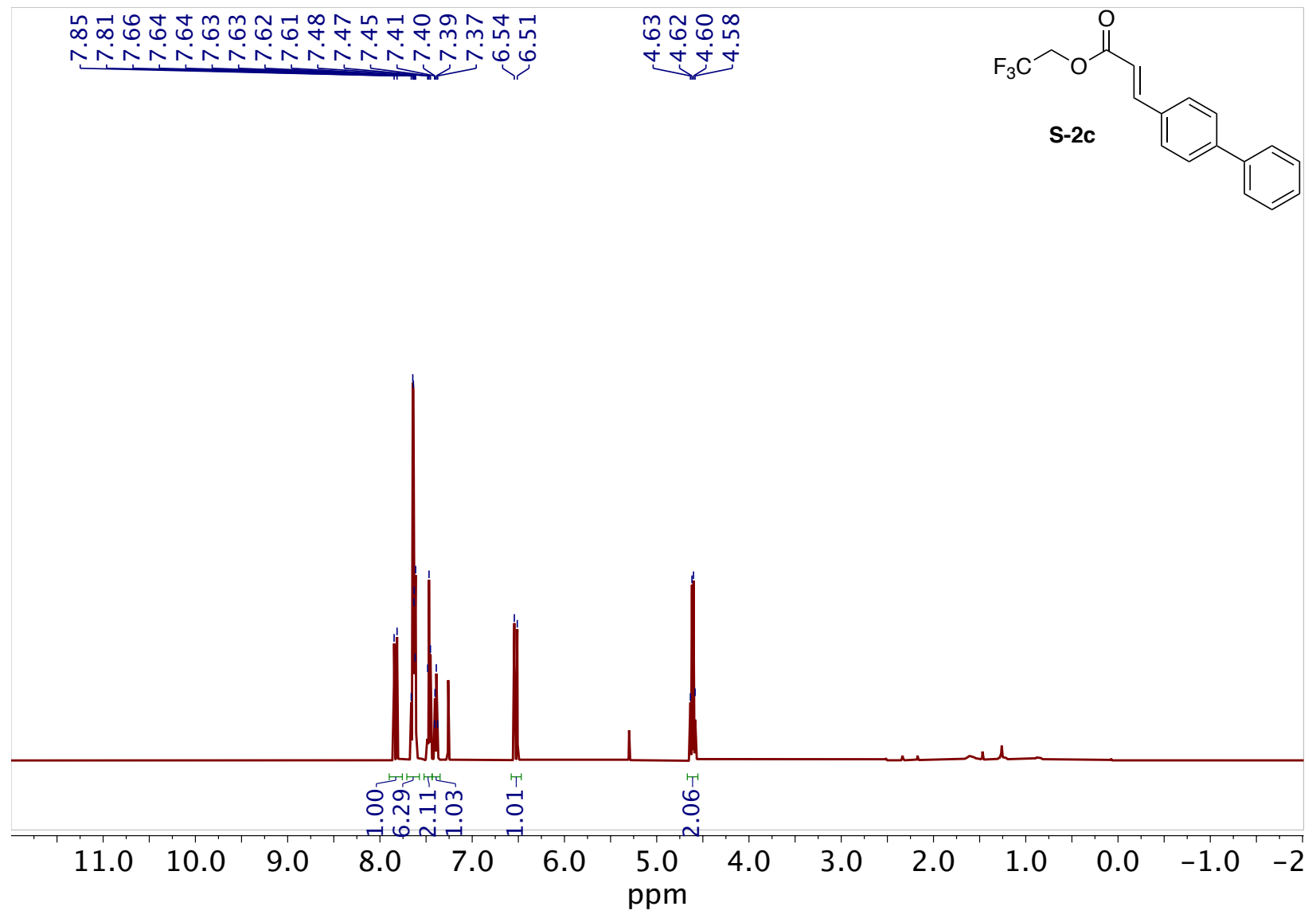


${ }^{13} \mathrm{C}, \mathrm{CDCl}_{3}, 125 \mathrm{MHz}$ of $\mathbf{S - 2 c}$

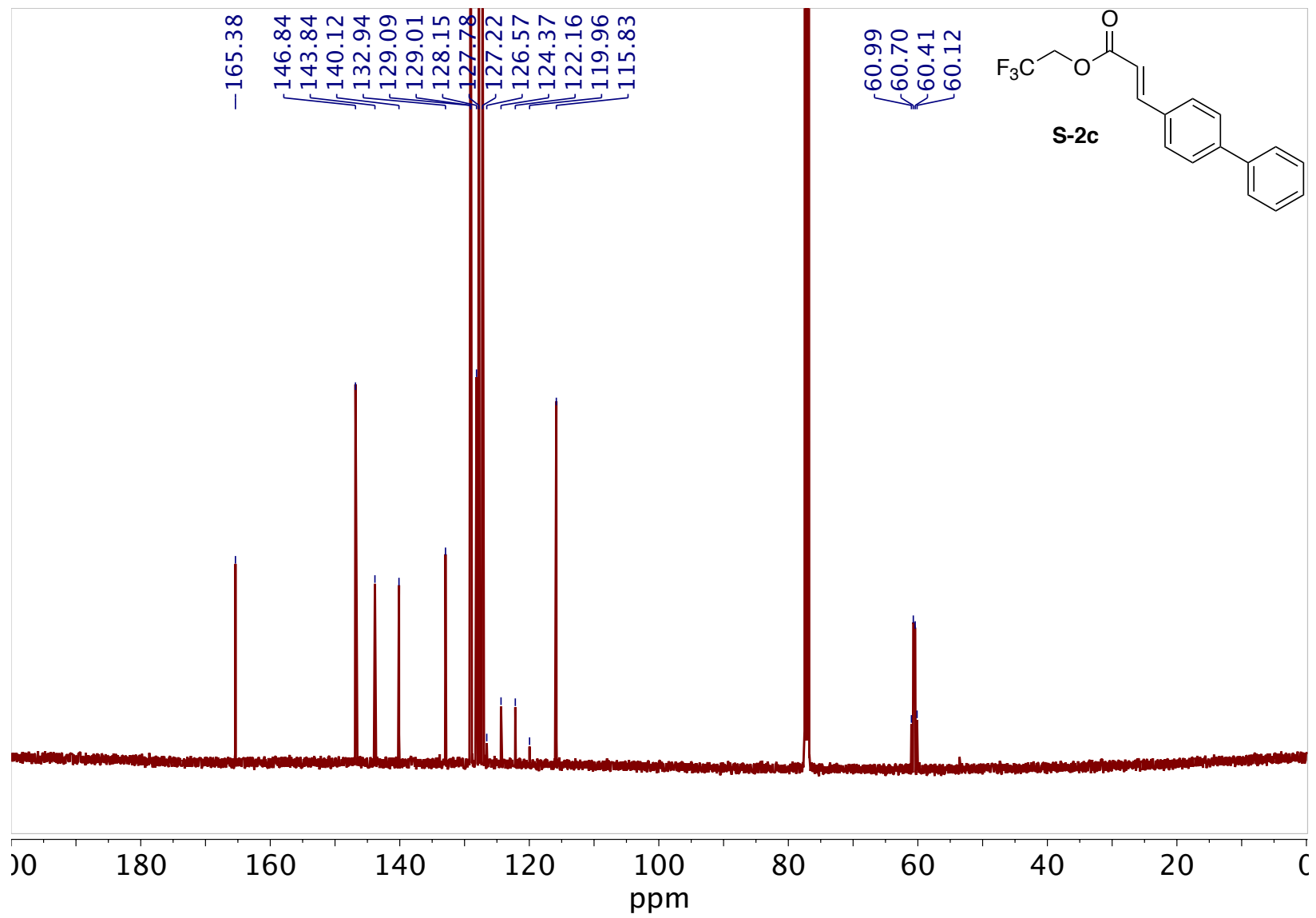




\section{${ }^{1} \mathrm{H}, \mathrm{CDCl}_{3}, 500 \mathrm{MHz}$ of $\mathbf{S - 3 b}$}

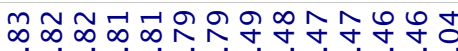

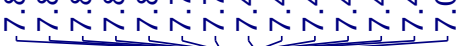

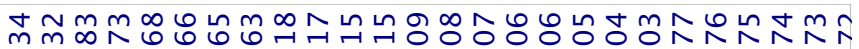

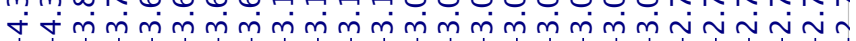

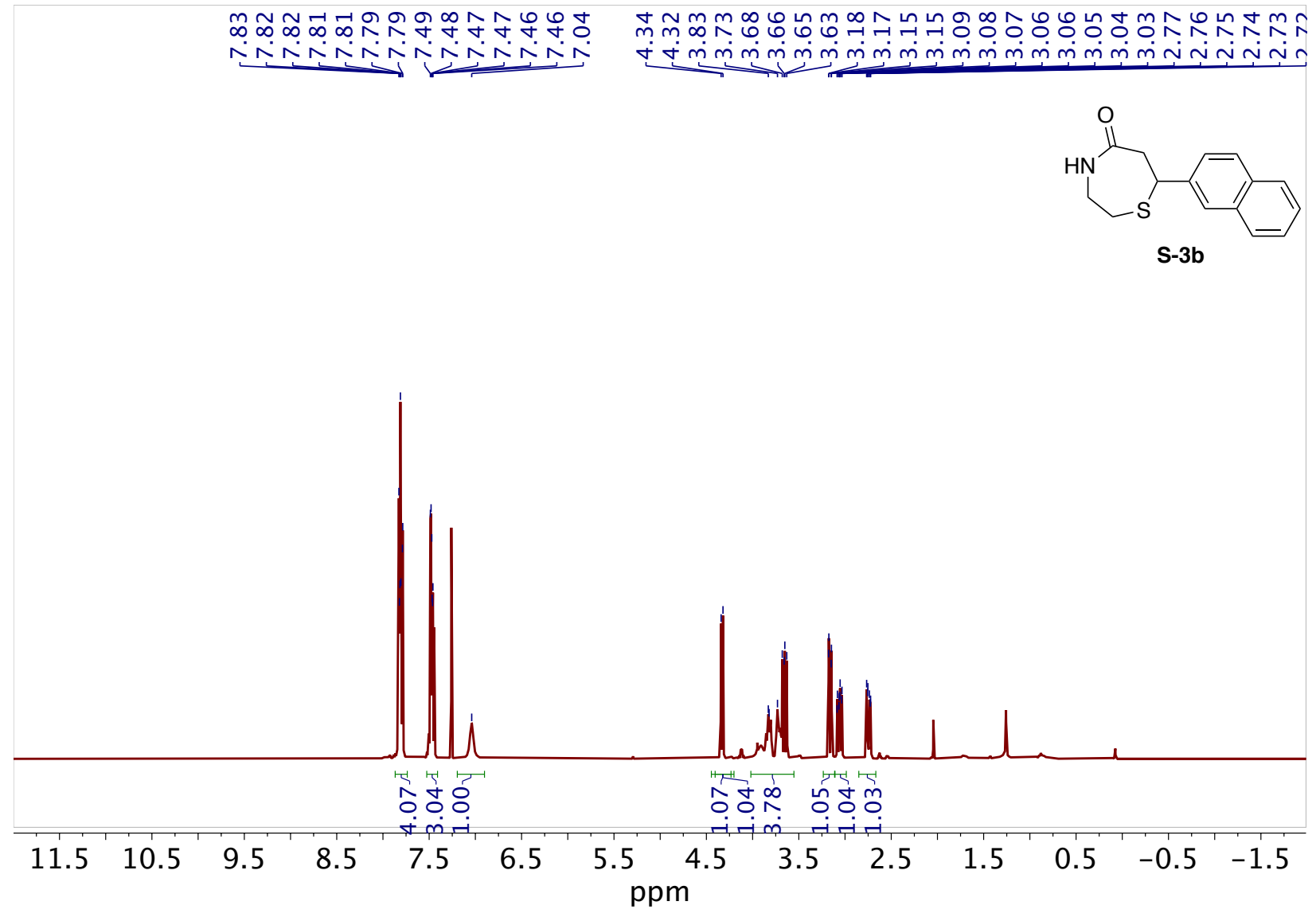


${ }^{13} \mathrm{C}, \mathrm{CDCl}_{3}, 125 \mathrm{MHz}$ of $\mathbf{S}-\mathbf{3 b}$

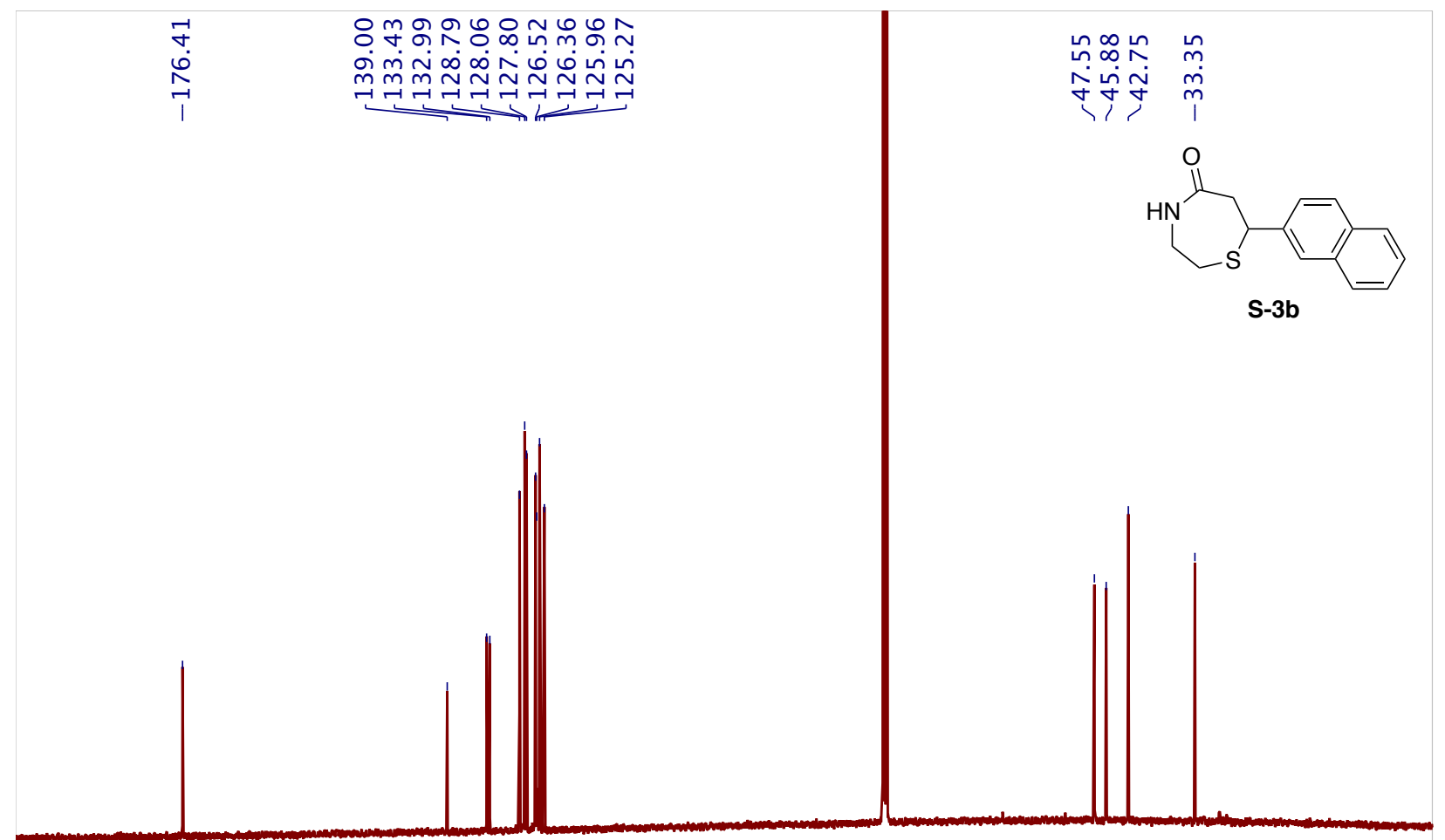

$\begin{array}{llllllllllllllllllllll}190 & 180 & 170 & 160 & 150 & 140 & 130 & 120 & 110 & 100 & 90 & 80 & 70 & 60 & 50 & 40 & 30 & 20 & 10 & \mathrm{C}\end{array}$ ppm 


\section{${ }^{1} \mathrm{H}, \mathrm{CDCl}_{3}, 500 \mathrm{MHz}$ of $\mathbf{S - 3 c}$}

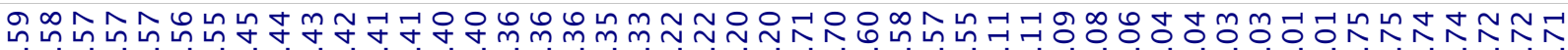

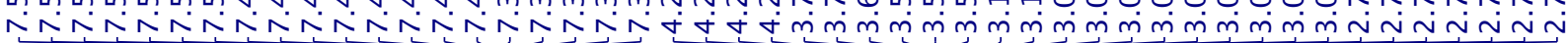

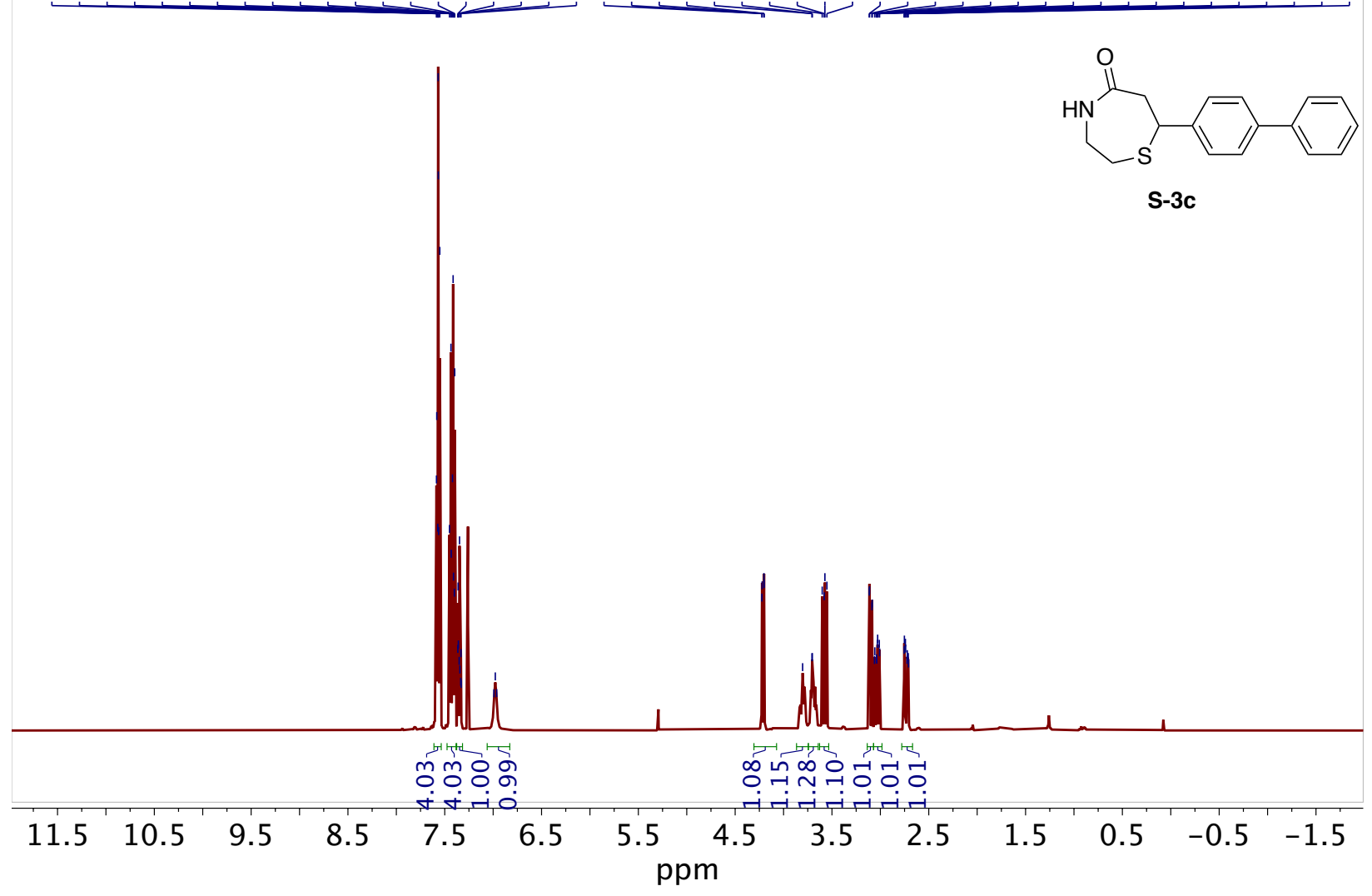


${ }^{13} \mathrm{C}, \mathrm{CDCl}_{3}, 125 \mathrm{MHz}$ of $\mathbf{S - 3 c}$

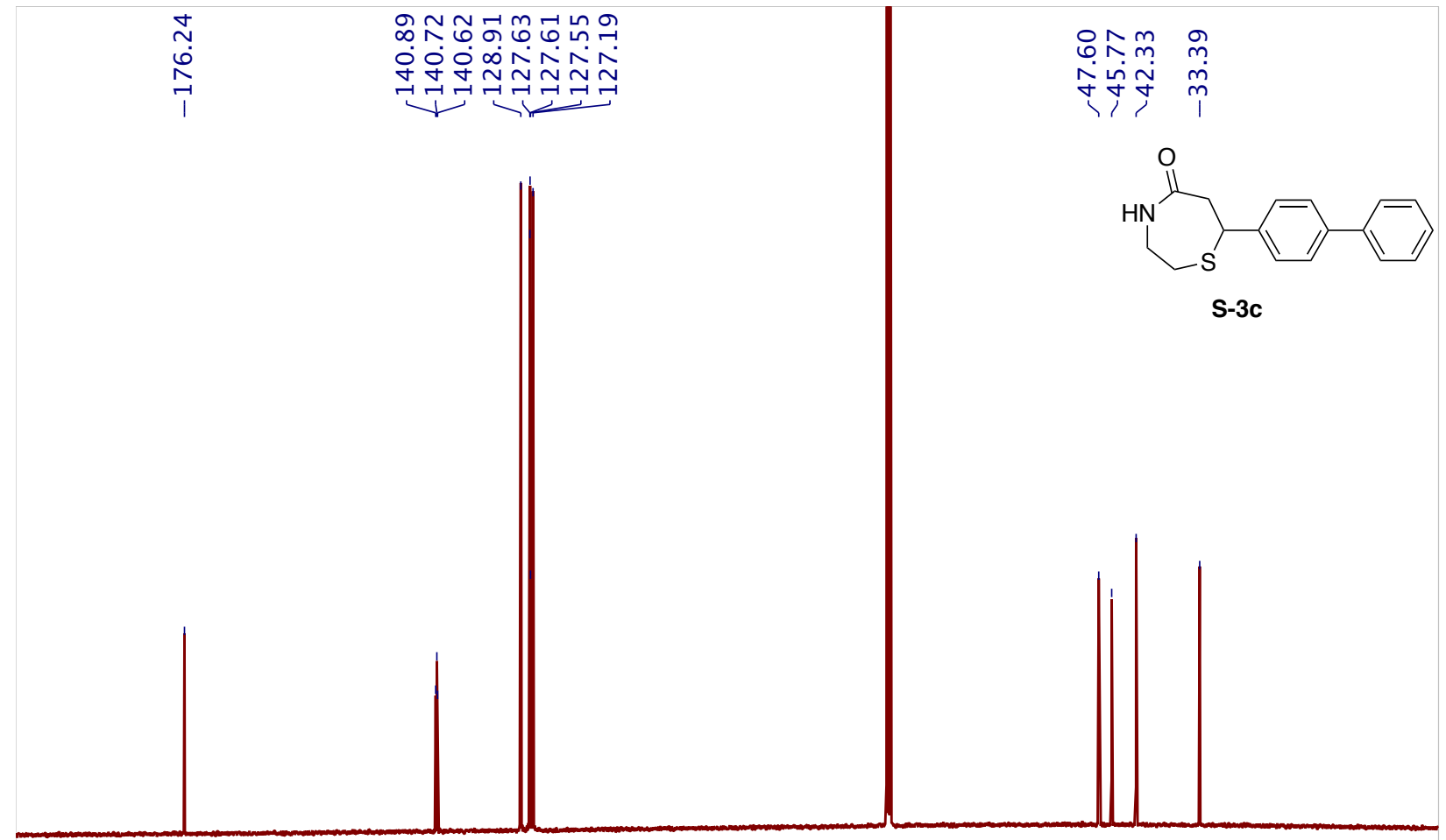

$\begin{array}{llllllllllllllllllllll}190 & 180 & 170 & 160 & 150 & 140 & 130 & 120 & 110 & 100 & 90 & 80 & 70 & 60 & 50 & 40 & 30 & 20 & 10 & \mathrm{C}\end{array}$ ppm 


\section{${ }^{1} \mathrm{H}, \mathrm{CDCl}_{3}, 500 \mathrm{MHz}$ of $\mathbf{T H}-\mathbf{1 1}$}

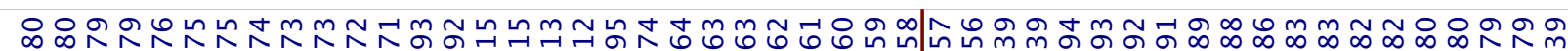

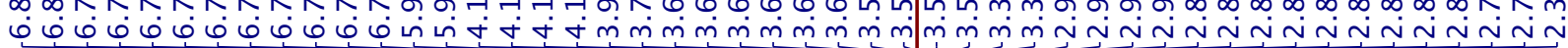

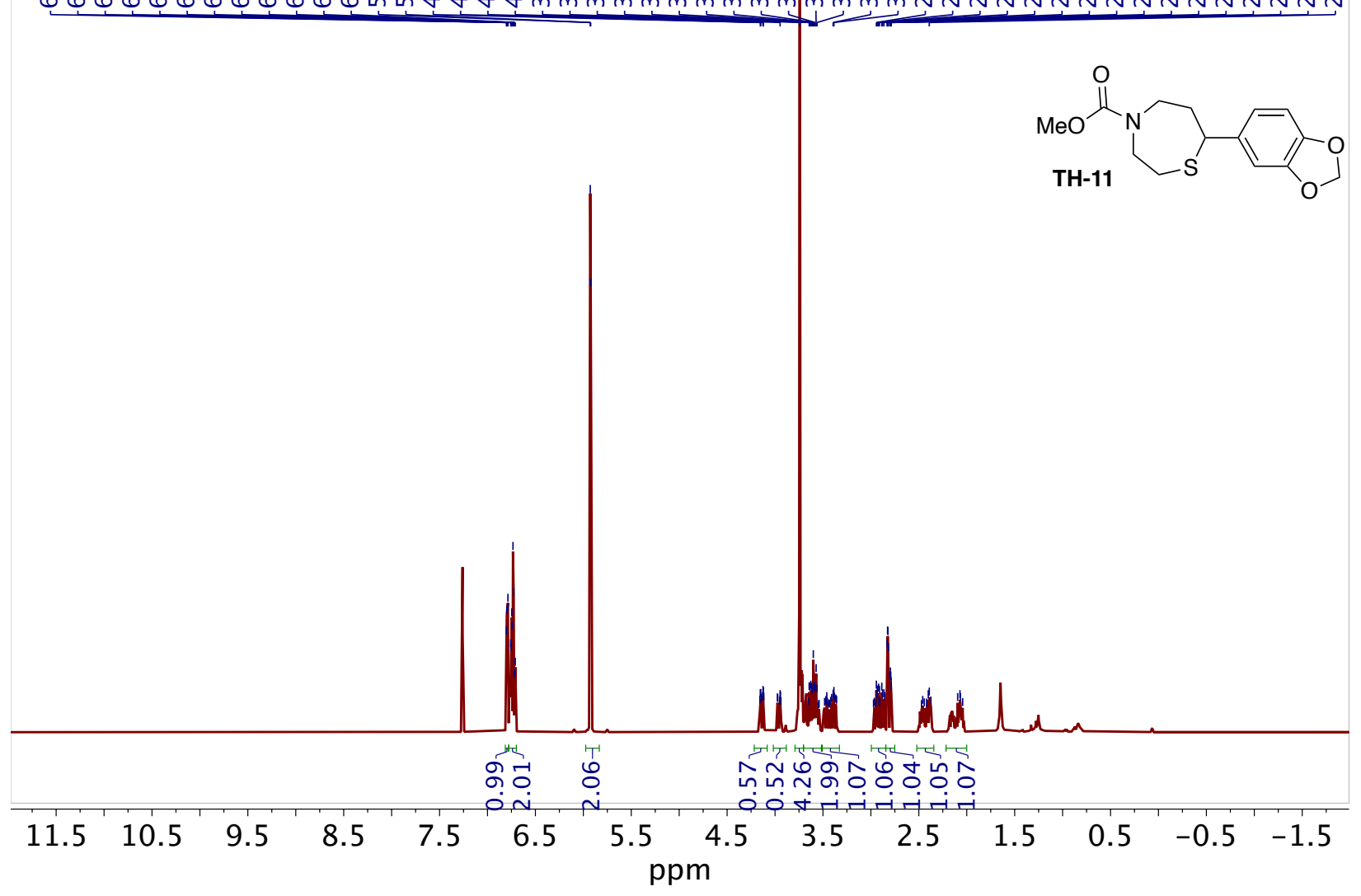


${ }^{13} \mathrm{C}, \mathrm{CDCl}_{3}, 125 \mathrm{MHz}$ of $\mathbf{T H}-\mathbf{1 1}$

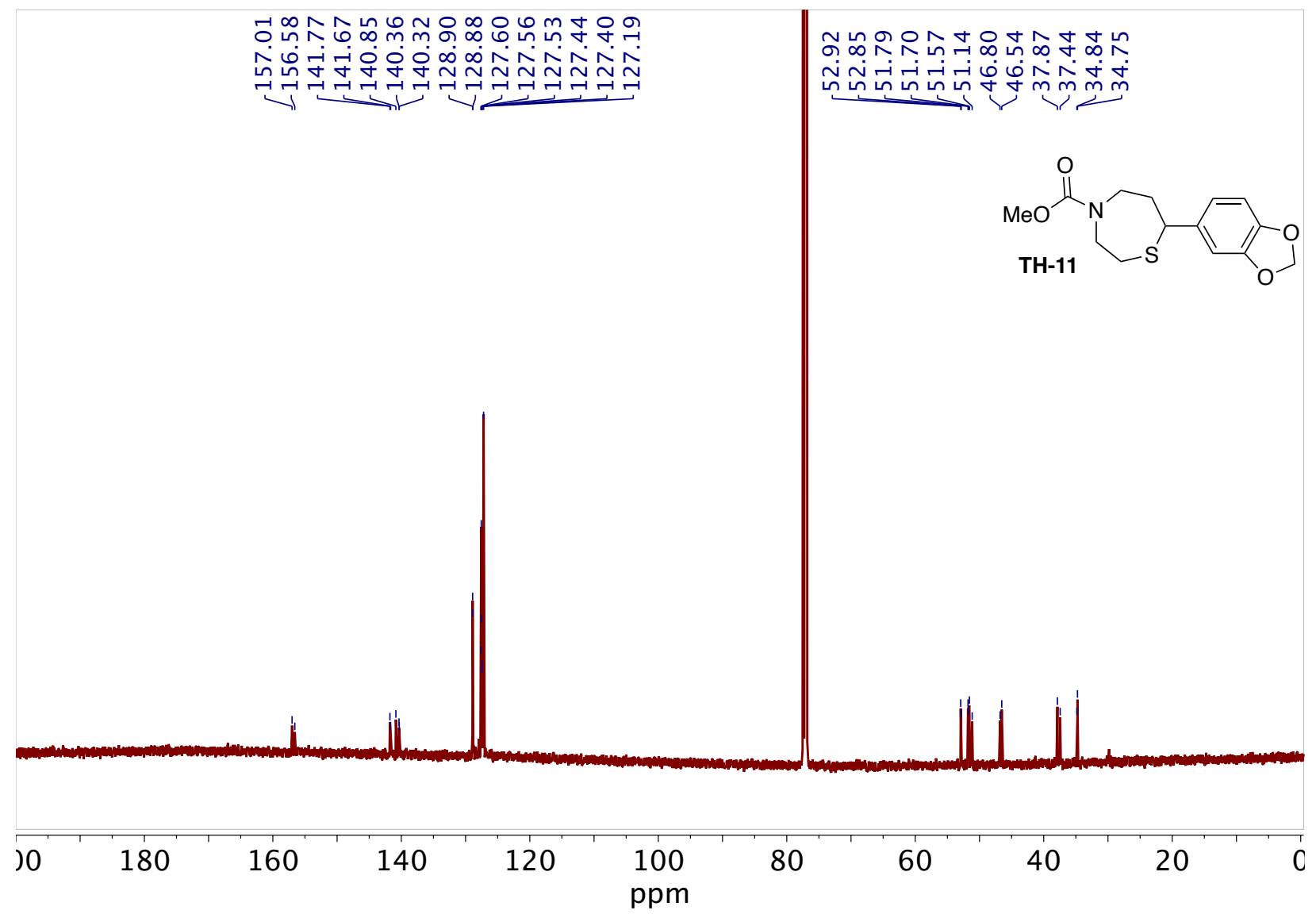




\section{${ }^{1} \mathrm{H}, \mathrm{CDCl}_{3}, 500 \mathrm{MHz}$ of $\mathbf{T H}-12$}

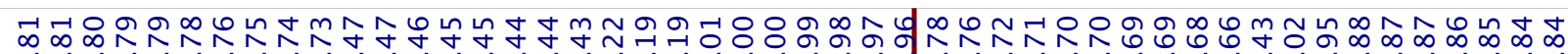

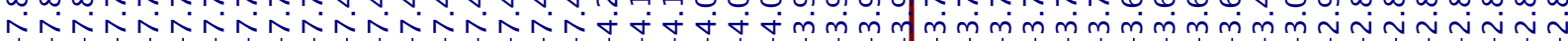

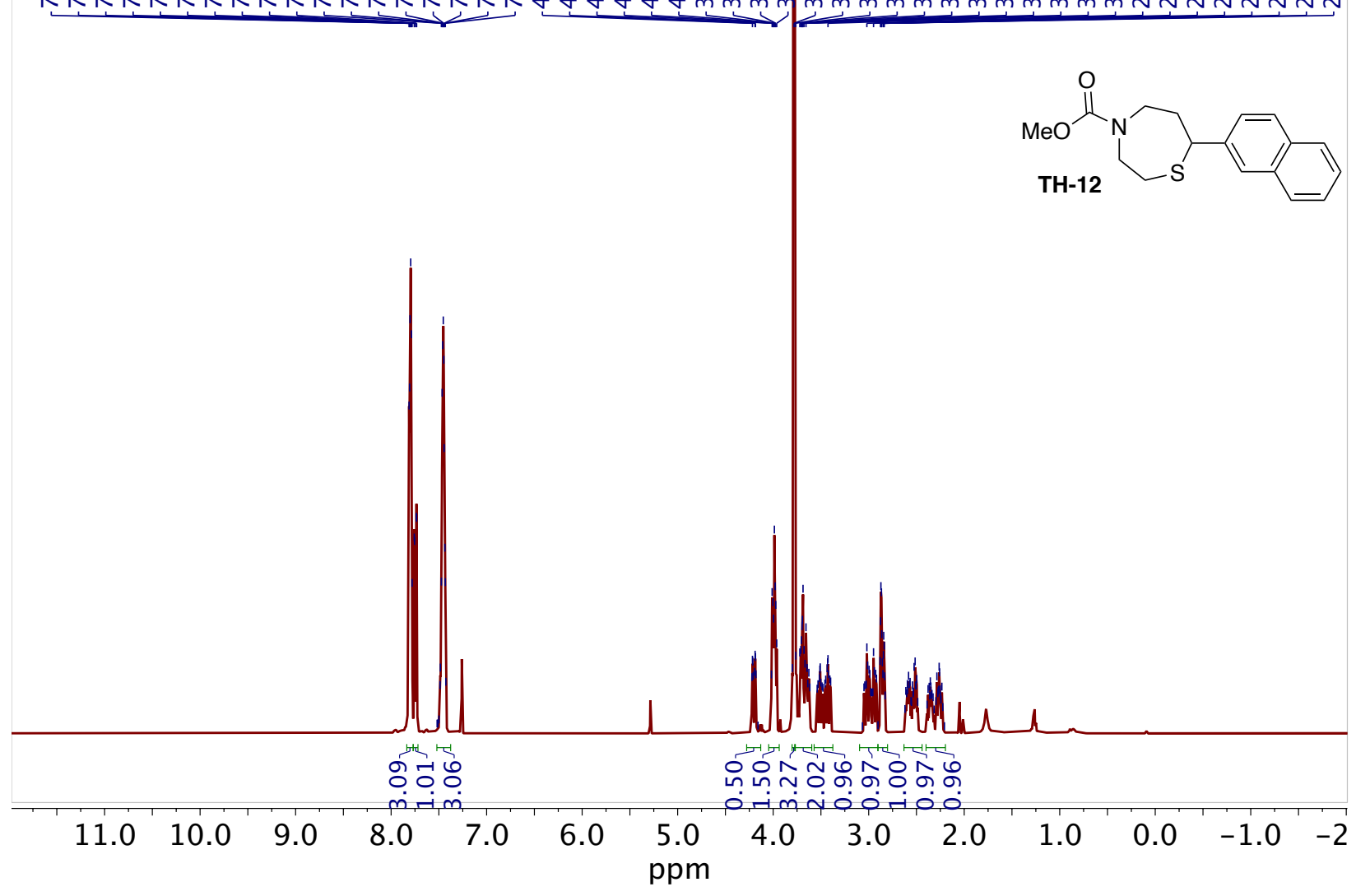


${ }^{13} \mathrm{C}, \mathrm{CDCl}_{3}, 125 \mathrm{MHz}$ of $\mathbf{T H}-\mathbf{1 2}$

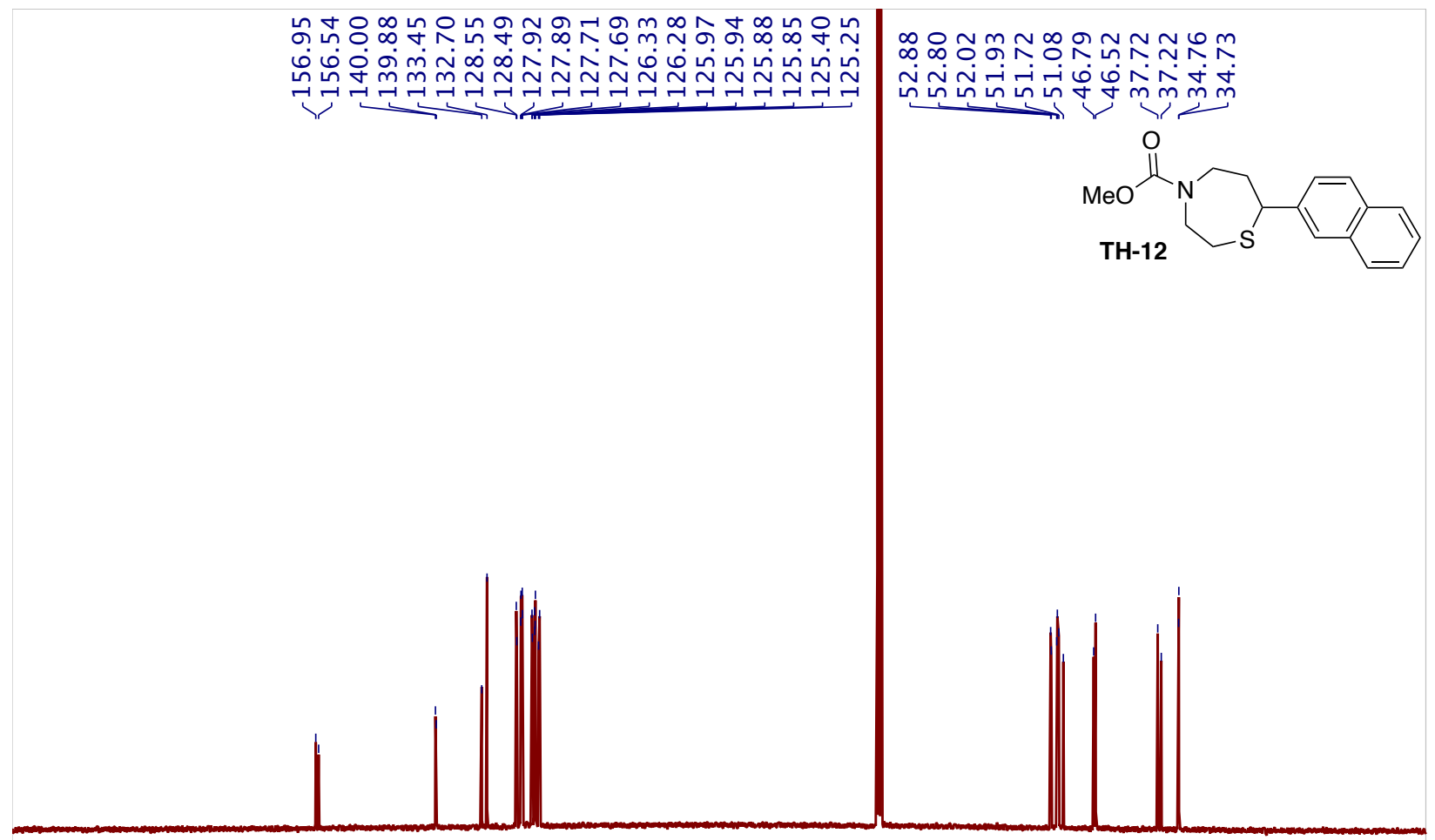

$\begin{array}{llllllllllllllllllll}190 & 180 & 170 & 160 & 150 & 140 & 130 & 120 & 110 & 100 & 90 & 80 & 70 & 60 & 50 & 40 & 30 & 20 & 10 & \mathrm{C}\end{array}$ ppm 


\section{${ }^{1} \mathrm{H}, \mathrm{CDCl}_{3}, 500 \mathrm{MHz}$ of $\mathbf{T H}-\mathbf{1 3}$}

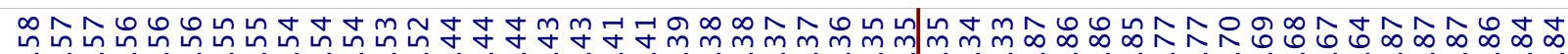

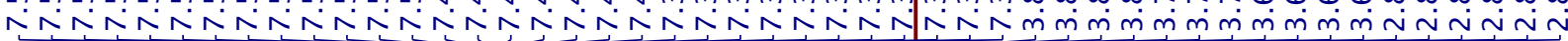

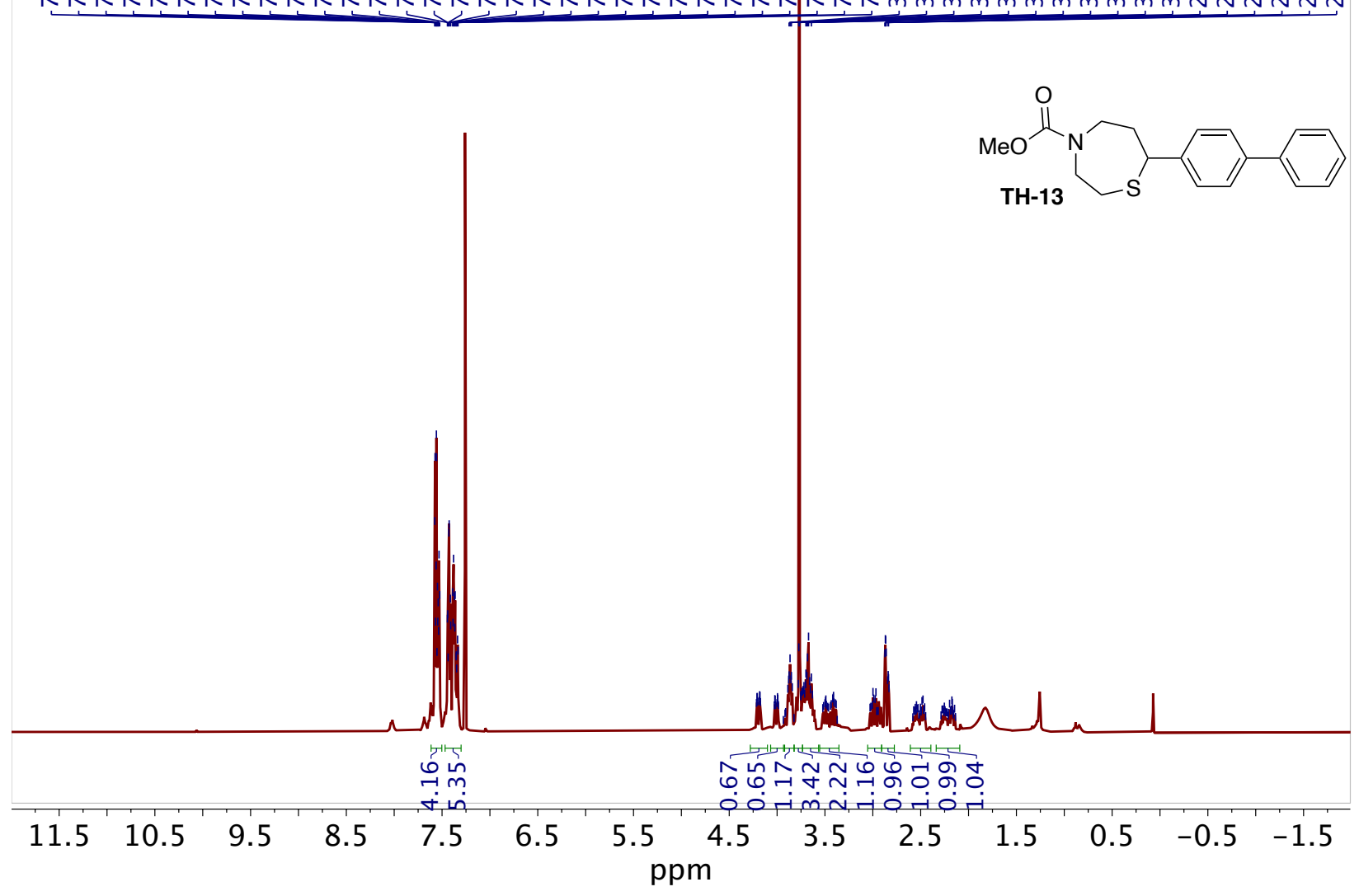


${ }^{13} \mathrm{C}, \mathrm{CDCl}_{3}, 125 \mathrm{MHz}$ of $\mathbf{T H}-\mathbf{1 3}$

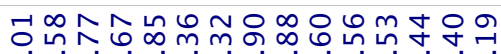

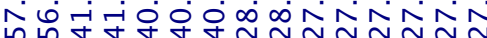

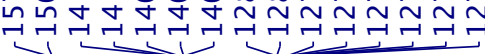

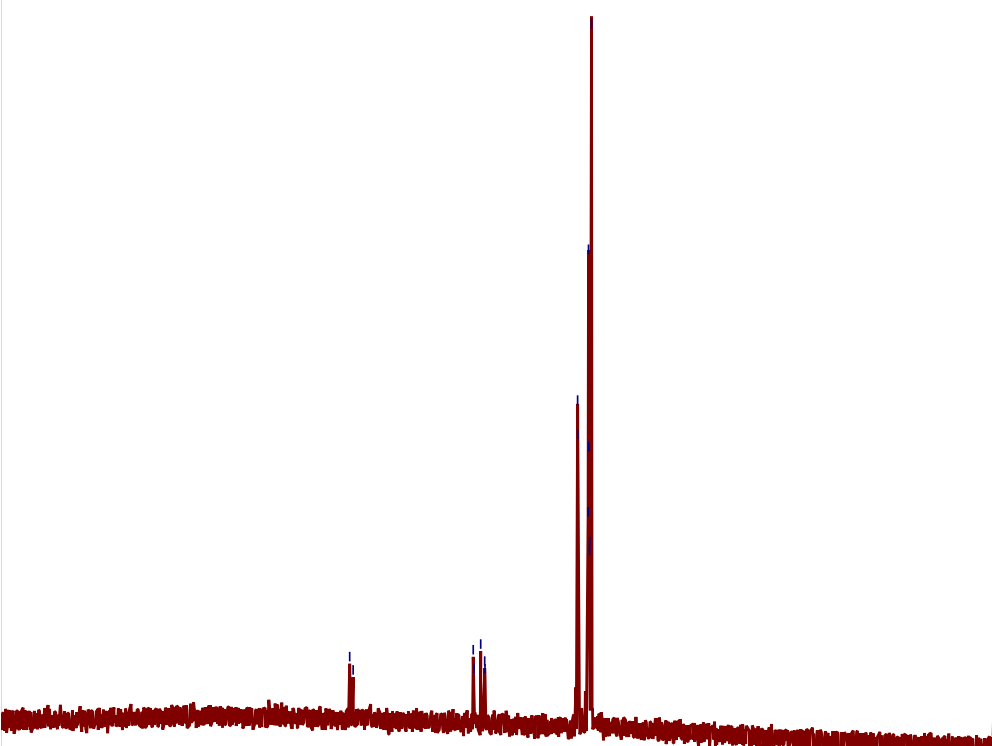

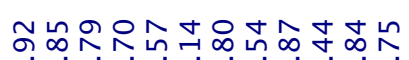

กี่

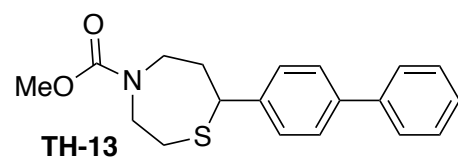

\begin{tabular}{lllllllllll}
\hline 0 & 180 & 160 & 140 & 120 & $\begin{array}{c}100 \\
\mathrm{ppm}\end{array}$ & 80 & 60 & 40 & 20 & $\mathrm{C}$
\end{tabular}


HPLC analytical purity traces for synthesized peptides. Peptide purity was assessed with a Dionex Ultimate RP-HPLC system using a Vydac C-18 column and a 0-50\% $\mathrm{CH}_{3} \mathrm{CN}$ gradient over 50 minutes. Traces are shown below.

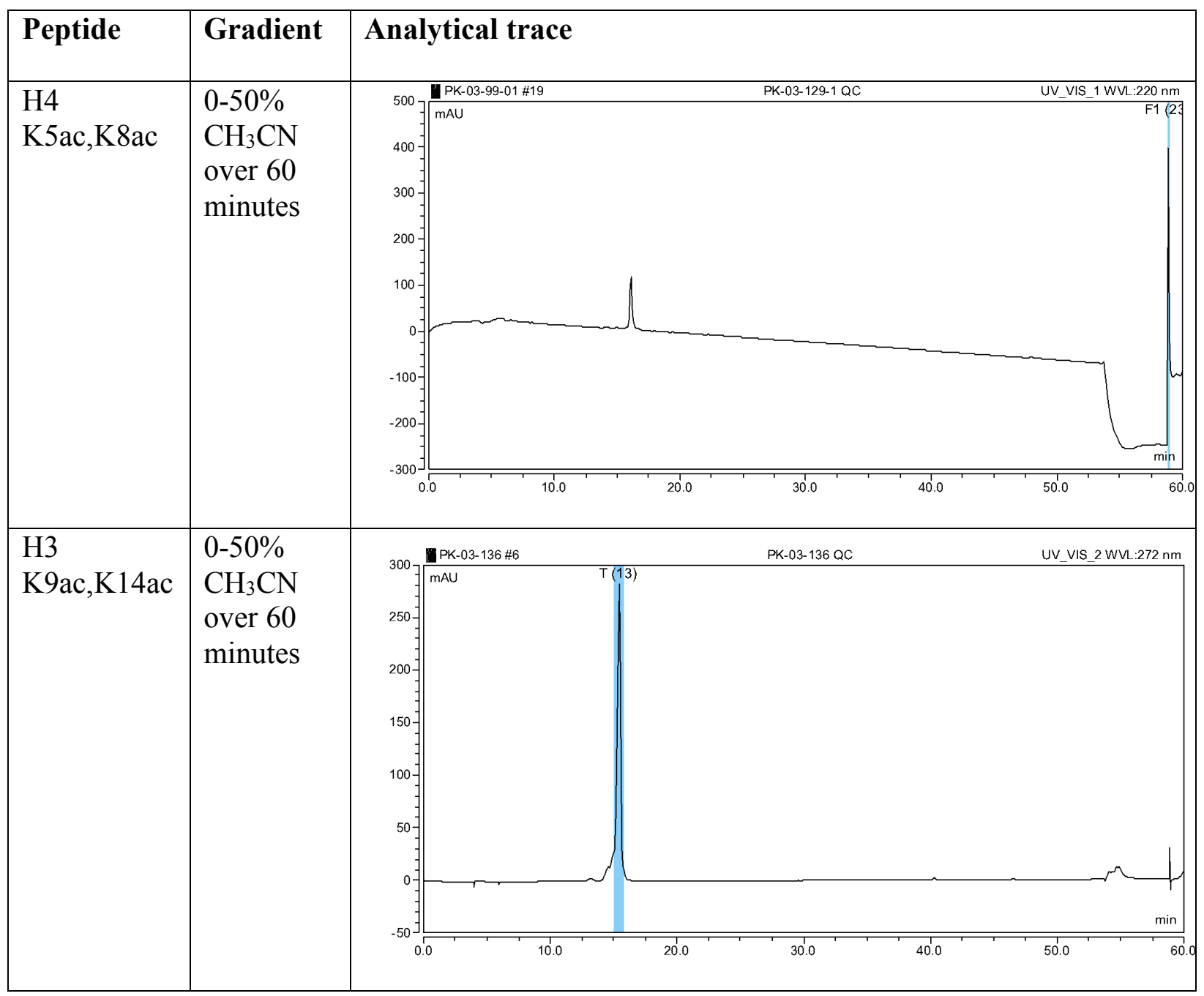




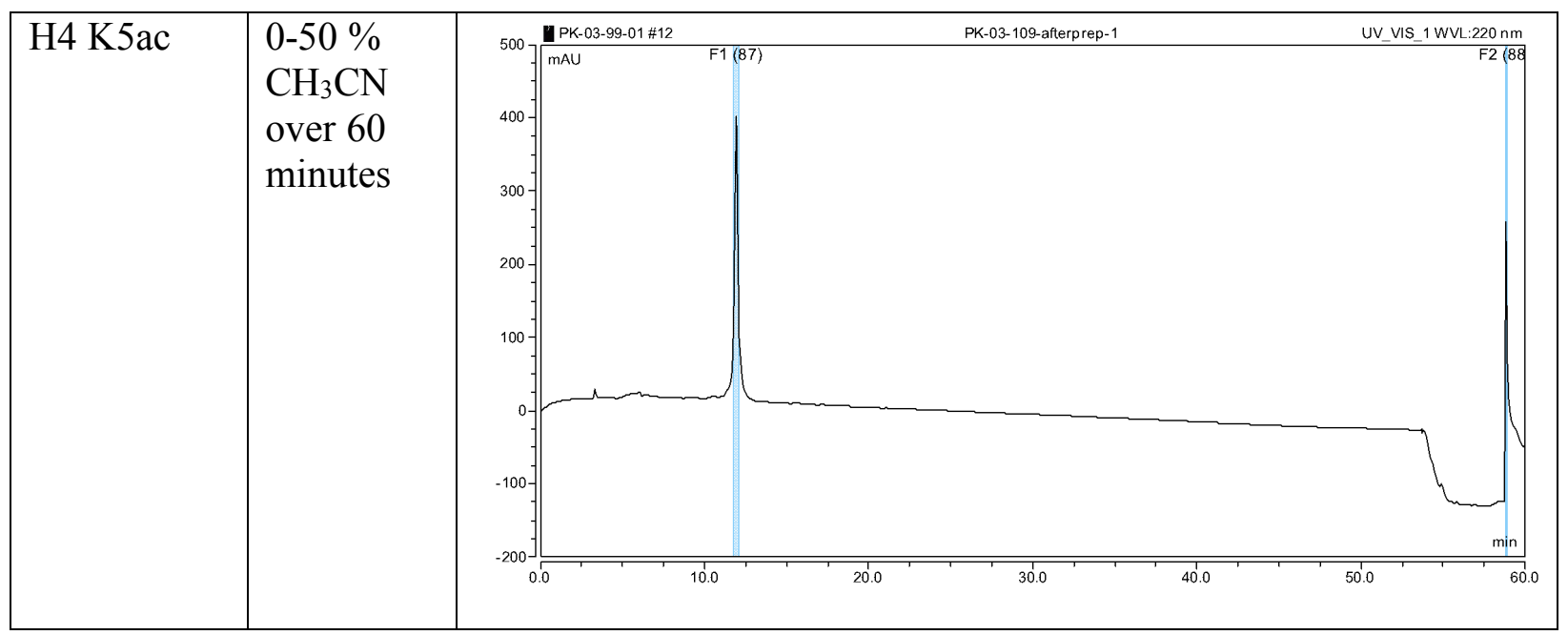

\section{References}

(1) Mishra, N. K.; Urick, A. K.; Ember, S. W. J.; Scho, E.; Pomerantz, W. C. Fluorinated Aromatic Amino Acids Are Sensitive 19F NMR Probes for Bromodomain-Ligand Interactions. ACS Chem. Biol. 2014, 9, 2755-2760.

(2) Paulson, C. N.; Guan, X.; Ayoub, A. M.; Chan, A.; Karim, R. M.; Pomerantz, W. C. K.; Schönbrunn, E.; Georg, G. I.; Hawkinson, J. E. Design, Synthesis, and Characterization of a Fluorescence Polarization Pan-BET Bromodomain Probe. ACS Med. Chem. Lett. 2018, 9 (12), 1223-1229. https://doi.org/10.1021/acsmedchemlett.8b00380.

(3) Johnson, J. A.; Nicolaou, C. A.; Kirberger, S. E.; Pandey, A. K.; Hu, H.; Pomerantz, W. C. K. Evaluating the Advantages of Using 3D-Enriched Fragments for Targeting BET Bromodomains. ACS Med. Chem. Lett. 2019, 10 (12), 1648-1654. https://doi.org/10.1021/acsmedchemlett.9b00414.

(4) Pandey, A. K.; Kirberger, S. E.; Johnson, J. A.; Kimbrough, J. R.; Partridge, D. K. D.; Pomerantz, W. C. K. Efficient Synthesis of 1,4-Thiazepanones and 1,4-Thiazepanes as 3d Fragments for Screening Libraries. Org. Lett. 2020, 22 (10), 3946-3950. https://doi.org/10.1021/acs.orglett.0c01230. 
